Pace University

DigitalCommons@Pace

$1-1-1983$

\title{
Protecting the Public Fisc: Fighting Accrual Abuse with Section 446 Discretion
}

Karl S. Coplan

Elisabeth Haub School of Law at Pace University

Follow this and additional works at: https://digitalcommons.pace.edu/lawfaculty

Part of the Accounting Law Commons, and the Law and Economics Commons

\section{Recommended Citation}

Karl S. Coplan, Protecting the Public Fisc: Fighting Accrual Abuse with Section 446 Discretion, 83 Colum. L. Rev. 378 (1983), http://digitalcommons.pace.edu/lawfaculty/363/.

This Article is brought to you for free and open access by the School of Law at DigitalCommons@Pace. It has been accepted for inclusion in Pace Law Faculty Publications by an authorized administrator of DigitalCommons@Pace. For more information, please contact dheller2@law.pace.edu. 


\section{Protecting the Public Fisc: Fighting Accrual Abuse with Section 446 Discretion}

Tax avoidance through accounting method manipulation has long plagued the income tax system. Section 446(b) of the current Internal Revenue Code of 1954 (the Code) is designed to combat such manipulations by requiring that accounting methods used for income tax reporting "clearly reflect income." ${ }^{\text {"1 }}$ But judicial application of this test has been confused. ${ }^{2}$ Though the Supreme Court has repeatedly stated that the Commissioner of Internal Revenue may determine as a matter of agency discretion whether a given accounting application clearly reflects income ${ }^{3}$ the source and nature of this grant of discretion have been left ambiguous. Also, the practical meaning of the "clearly reflect income" language has never been articulated. Courts have relied on section 446(b) to disallow manipulations of cash method accounting, ${ }^{4}$ but no court has squarely addressed the potential for accrual accounting manipulation. ${ }^{5}$ Uncertainty about the application of section 446 (b) to accrual accounting has left the door open to manipulation.

This Note suggests an approach under the current Code and current legal doctrine that would enable the Commissioner to disallow accrual accounting when manipulated to avoid taxation. At the outset, the Note defines and illustrates tax avoidance through accounting manipulation. The Note then considers within the framework of judicial review of agency action the source and nature of the Commissioner's discretion to reject accounting methods. This analysis demonstrates the validity of the Commissioner's action whenever it is based on legally relevant factors. The Note then develops the emerging content of the "clearly reflect income" language as the source of the legally relevant factors, and concludes that the relationship between the notion of "income" and taxation according to ability to pay supports the Commissioner's rejection of an accounting method manipulated to avoid normal payment of tax.

1. I.R.C. $\S 446$ (b) (1976).

2. Note the current conflict between the Court of Claims and the Fifth Circuit over the deductibility of tax shelter farmers' prepaid feed expenses, challenged by the Commissioner under $\S 446$ (b). Compare Clement v. United States, 580 F.2d 422 (Ct. Cl. 1978) (deduction denied), with Frysinger v. Commissioner, 645 F.2d 523 (5th Cir. 1981) (deduction allowed).

3. Thor Power Tool Co. v. Commissioner, 439 U.S. 522, 532-33 (1979), and cases cited therein.

4. E.g., Ferrill v. Commissioner, 684 F.2d 261 (3d Cir. 1982); Burck v. Commissioner, 533 F.2d 768 (2d Cir. 1976).

5. When confronted with such an accrual accounting manipulation in Mooney Aircraft, Inc. v. United States, 420 F.2d 400 (5th Cir. 1969), the Fifth Circuit disallowed the accounting practice under $\S 446(\mathrm{~b})$, but did not properly identify the manner in which accrual accounting was being manipulated. See discussion infra notes 37-42 \& 170-71 and accompanying text. 


\section{Tax Avomance Abuse of Accrual Accounting}

\section{A. Avoidance Abuse Defined}

Implicit in a system of income taxation is the goal of vertical equity. ${ }^{6}$ Vertical equity requires that those with greater ability to pay tax pay a higher tax. Equally necessary to an economically workable system of income taxation are the goals of horizontal equity and economic efficiency. ${ }^{7}$ Horizontal equity requires that similarly situated taxpayers pay an equal tax. If horizontal equity is defeated, vertical equity will also be defeated. ${ }^{8}$ Economic efficiency requires that the tax system not favor one equally economically efficient transaction over another. ${ }^{9}$ If similarly situated taxpayers pay different taxes, the transaction yielding the lower tax becomes artificially favored, thereby defeating free market economic efficiency. Of course, all three goals are considerably modified by tax incentive provisions of the Code, which intentionally distort free market efficiency as well as vertical and horizontal equity in order to encourage certain activities. For the purposes of this Note, the calculus of vertical equity, horizontal equity, and efficiency as modified by intentional subsidy provisions will be referred to as "tax equity."

Within this framework, a tax shelter may be defined as any transaction that reduces current income tax without reducing the taxpayer's actual wealth and, by implication, without reducing his current ability to pay tax..$^{10}$ Not all tax shelters are "abusive." If the activity giving rise to the tax reduction is the intended recipient of a tax subsidy, the reduction in taxes is simply the government's way of paying the subsidy. ${ }^{11}$

Consider a transaction that, after applying all the rules of the taxpayer's usual book accounting method, results in a decrease in his tax for the current year. Such a transaction might actually have decreased the taxpayer's ability to pay tax, in which case the reduction in tax does not defeat tax equity. ${ }^{12}$ Alternatively, the transaction might not decrease the taxpayer's ability to pay tax, or might cause a decrease in tax disproportionate to the decrease in taxpaying ability. If so, the transaction is a "tax shelter." Assuming that the tax benefits are the result of activities qualifying for an intentional tax subsidy, tax equity is not defeated; the goals of vertical and horizontal equity are sacrificed to serve governmental policy considered more important. If, on the other hand, a transaction reduces the tax without reducing ability to pay and is not a transaction for which a tax subsidy was intended, tax equity is

6. R. Musgrave \& P. Musgrave, Public Finance in Theory and Practice 235 (1980).

7. Id.

8. Horizontal equity is intertwined with vertical equity, since, if similarly situated taxpayers pay a different tax, vertical equity is destroyed. The taxpayer paying less than those similarly situated must be paying the same as some other taxpayer less able to pay the tax, so that the tax is no longer proportional to ability to pay.

9. R. Musgrave \& P. Musgrave, supra note 6 , at 235.

10. See Shefsky, Take the Helter out of Shelter, 58 Taxes 299, 300-01 (1980).

11. Id.; R. Musgrave \& P. Musgrave, supra note 6, at 358.

12. This transaction is not a tax shelter, since actual wealth is decreased. 
defeated. The latter situation-a transaction that avoids payment of taxes according to taxpaying ability without participation in a tax-favored activitycan be defined as tax avoidance abuse. ${ }^{13}$ This definition does not consider intent: the same form of transaction may be entered into by one taxpayer to avoid taxes and by another for nontax economic reasons. ${ }^{14}$ Adherence to the taxpayer's regular book accounting method ${ }^{15}$ may require the taxpayer to claim unsought tax benefits. To the extent that the avoidance-motivated taxpayer and the innocent taxpayer remain equally able to pay tax, however, tax equity does not require the law to discriminate between them on the basis of intent. ${ }^{16}$

\section{B. Accrual Accounting as Abusive}

1. Can an Accounting Method Be Abused? Both cash and accrual methods are specifically authorized by section 446 (c) of the Code for computation of taxable income. ${ }^{17}$ Given that the Code ultimately defines tax "income" in terms of the tax accounting method used, the possibility that the proper application of an authorized accounting method could be an abuse not properly reflecting income seems puzzling. Yet section $446(\mathrm{~b})$ contemplates exactly that possibility in providing that "if the [accounting] method used does not clearly reflect income, the computation of taxable income shall be made under such method as, in the opinion of the [Commissioner], does clearly reflect income." 18 This provision expressly applies to the accounting methods autho-

13. This Note does not attempt to deal with the possible abuse situation in which the taxpayer tries to take disproportionate advantage of intended tax subsidies.

14. Compare the rent-accrual shelter discussed infra text accompanying notes 26-27 with the rent payment arranged by the taxpayer in Grand Ave. Motor Co. v. United States, 124 F. Supp. 423 (D. Minn. 1954).

15. "Taxable income shall be computed under the method of accounting on the basis of which the taxpayer regularly computes his income in keeping his books." I.R.C. $\$ 446$ (a) (1976).

16. On the irrelevance of tax-avoidance intent to the question of abuse, see Frysinger v. Commissioner, 645 F.2d 523, 527-28 (5th Cir. 1981) (treasurer of U.S. Steel Corporation claimed a large deduction for prepaid feed in a cattle management syndicate; despite the taxpayer's evident intent to avoid taxes the court found sufficient "business purpose" to qualify for special treatment given by the Treasury Regulations to farmers); Helvering v. Gregory, 69 F.2d 809, 810 (2d Cir. 1934) ("[A] transaction, otherwise within an exception of the tax law, does not lose its immunity, because it is actuated by a desire to avoid . . . taxation."), aff'd, 293 U.S. 465 (1935).

17. "[A] taxpayer may compute taxable income under any of the following methods of accounting-(1) the cash receipts and disbursements method; (2) an accrual method . . .."I.R.C. $\S 446(c)$ (1976).

The regulations define these accounting methods as follows:

(i) Cash receipts and disbursements method. Generally, under the cash receipts and disbursements method in the computation of taxable income, all items which constitute gross income (whether in the form of cash, property, or services) are to be included for the taxable year in which actually or constructively received. Expenditures are to be deducted for the taxable year in which actually made .... .

(ii) Accrual method. Generally, under an accrual method, income is to be included for the taxable year when all the events have occurred which fix the right to receive such income and the amount thereof can be determined with reasonable accuracy. Under such a method, deductions are allowable for the taxable year in which all the events have occurred which establish the fact of the liability giving rise to such deduction and the amount thereof can be determined with reasonable accuracy.

Treas. Reg. $\$ 1.446-1$ (c)(1) (1957).

18. I.R.C. $§ 446(b)(1976)$. 
rized in section 446 (c).${ }^{19}$ In addition, because relative ability to pay may not be definable by any particular set of accounting rules, a tax system based on ability to pay will not be served in every situation by a specific accounting method. Since the accounting rules are designed to reflect taxpaying ability in the ordinary situation, unusual circumstances affecting taxpaying ability might not be considered. Where the inherent inaccuracies of an accounting method are exploited through the structuring of transactions, tax liability will not reflect taxpaying ability, tax equity is defeated, and the accounting method may be said to be abused. Case law on cash method accounting under section 446(b) amply supports the contention that an accounting method may be abused. The weakness of cash accounting is that no attempt is made to match revenues and expenses; the taxpayer has broad discretion in the timing of deductions. Thus, the cash rules allow a current deduction for expenses paid even though the associated income is not currently recognized. Alternatively, future expenses may be paid and deducted currently without capitalizing their value. ${ }^{20}$ Such current deductions permit the taxpayer to take advantage of the time value of deferred taxes and are susceptible to disallowance.

Circuit courts have rejected these cash method deductions. These courts have relied on the evolving rule that the determination that an accounting method does not "clearly reflect income" under section 446(b) is a matter for the discretion of the Commissioner. ${ }^{21}$ Where transactions are structured to take advantage of the cash method's inaccuracies by providing for extraordinary expense prepayments, courts usually are quick to uphold a Commissioner's determination that income is not clearly reflected. In Burck v. Commissioner, ${ }^{22}$ the Second Circuit upheld such a determination where the cash method taxpayer had prepaid $\$ 300,000$ of interest on a five-year loan in order to offset a $\$ 900,000$ capital gain in the tax year. The court held that "prepaid interest expense, just as in the case of any other substantial prepaid item, may, in individual situations, appropriately be recognized by the Commissioner as an item which materially distorts the reporting and taxation of a cash basis taxpayer's income." ${ }^{23}$ The Burck court's disallowance of cash accounting for

19. Section $446(\mathrm{c})$, aunorizing the cash method and the accrual method, is "[s]ubject to the provisions of subsection[] . . . (b)." I.R.C. § 446(c) (1976).

20. But see Treas. Reg. § 1.461-1(a)(1) (1957) (deduction denied where asset had useful life extending beyond taxable year in which asset was created).

21. See discussion of Commissioner's discretion infra text accompanying notes 51-119.

22. 533 F.2d 768 (2d Cir. 1976).

23. Id. at 773. It should be noted that the "materially distort income" language derives from Treas. Reg. § 1.461-1(a)(3)(i) (1957), dealing with items that "overlap" taxable years. Since § 461 does not expressly mention this concept, but implicitly incorporates $\S 446$ through its reference to taxpayer's accounting method, this language would seem to be a rephrasing of the "clearly reflect income" test of $\S 446(\mathrm{~b})$. See generally discussion of "clearly reflect income" infra text accompanying notes $120-59$.

In accord with Burck are Ferrill v. Commissioner, 684 F.2d 261 (3d Cir. 1982) (prepaid interest); Cole v. Commissioner, 586 F.2d 747 (9th Cir. 1978) (same); Sandor v. Commissioner, 536 F.2d 874 (9th Cir. 1976) (same); Keller v. Commissioner, 79 T.C. 2 (1982) (prepaid intangible drilling costs). Section 461(g), added by the Tax Reform Act of 1976, 90 Stat. 1520, codifies this case law by requiring cash method taxpayers to capitalize prepaid interest. I.R.C. $\S 461(\mathrm{~g})$ (1976). Compare Clement v. United States, 580 F.2d 422 (Ct. Cl. 1978) (prepaid feed deduction denied), 
a transaction that exploits cash accounting's weakness has not yet been extended to the disallowance of accrual accounting for transactions exploiting its rules to avoid taxes.

2. Accrual Accounting Distortion. Accrual accounting's weakness is its failure to take into account the time value of money. As interest rates have skyrocketed, the potential for real profit by manipulation of this shortcoming of accrual accounting has increased.

Consider the situation of two taxpayers, $A$ and $B$, each running an identical service business and keeping his books on the accrual basis. Each rents identical premises and each has net income for the year, before any deduction for rent, of $\$ 20,000$. Taxpayer $A$ has a lease that provides for $\$ 6,000$ annual rent, payable on January 15 th following each year. "All events" having occurred to fix the liability, and the amount being "reasonably determinable," the Treasury Regulations (Regulations) permit deduction of the expense, ${ }^{24}$ and $A$ duly accrues as payable the $\$ 6,000$ rent for the year in filing a return for the year ended December 31st, reporting net income of $\$ 14,000 . B$ is a more aggressive taxpayer. He has arranged for a lease under which rent for the year is due in the amount of $\$ 15,000$, payable ten years after the close of the taxable year. On January 15th of the next year he purchases $\$ 6,000$ worth of tax free bonds yielding ten percent, knowing that in ten years this sinking fund will equal the $\$ 15,000$ needed to pay the accrued rent obligation. On his tax return for the year ended December 31 st, $B$ accrues the entire amount of the $\$ 15,000$ rent due in ten years, since "all events" have occurred that fix the fact of his liability and the amount of the liability is precisely determinable. $B$ reports $\$ 5,000$ of income for the year, while $A$ reports $\$ 14,000$, even though their taxpaying abilities are identical. ${ }^{25}$ Thus, by manipulation of the weakness of accrual accounting-the failure to consider the time value of money $-B$ is able to defeat horizontal equity unless the Code provides a remedy.

cert. denied, 440 U.S. 907 (1979), with Frysinger v. Commissioner, 645 F.2d 523 (5th Cir. 1981) (prepaid feed not disallowable as against authorization in Treasury Regulations).

24. The "all events" and "amount reasonably determinable" criteria are the two prongs of the test for timing of an accrual deduction. Treas. Reg. $\$ 1.461-1(a)(2)(1957)$; United States v. Anderson, 269 U.S. 422 (1926).

25. If anything, $B$ is in a better position to pay tax, since he has greater liquidity than $A$, who has actually given up the $\$ 6,000$ by the time the tax is due.

This hypothetical might also be phrased in terms of vertical equity or economic efficiency. If $A$ 's rent were $\$ 15,000$, payable 15 days after the close of the year, $A$ and $B$ would pay the same tax. But since the $\$ 15,000$ due in ten years is costing only $\$ 6,000, B$ is in a better position to pay tax. Since $B$ 's tax liability would not be proportional to his ability to pay tax, verticial equity would be defeated. Economic efficiency considerations suggest a similar problem. If rent is payable as in the text hypothetical, $A$ and $B$ are making the same discounted payment for their premises. $B$ has been induced to rent inferior premises, however, by the landlord's agreement to this deferral scheme, since the tax savings reduce $B$ 's after tax initial cost to below the fair market value of the inferior premises. By encouraging $B$ to enter an otherwise inefficient transaction (assuming superior premises were available for the $\$ 6,000$ rent), the tax system would be distorting an economically efficient market. 
Such a shelter scheme has real-life applications in sale-leaseback transactions. ${ }^{28} \mathrm{~A}$ buyer-lessor using the cash method ${ }^{27}$ will not be taxed on the "rent" until actually paid, so it is perfectly happy to defer payment of a portion of the "rent" (assuming that the seller-lessee is a good credit risk) if the dollar amount is increased to make up for the time value of the deferral. A taxexempt buyer-lessor would be equally amenable to such a transaction. The long-term lease might provide for low cash payments initially, with increased payments at the end of the lease more than a decade later, while providing for liability to "accrue" at a flat rate over the life of the lease. The accrualmethod seller-lessee would then claim a current rent deduction equal to the flat rate allocation of the total payments due under the lease, even though little or no cash payment is due at the outset. ${ }^{28}$ (This flat rate allocation is

26. Besides the accounting issues suggested herein, such sale-leasebacks run the danger of recharacterization as financing transactions, or disallowance as lacking economic substance. Hilton v. Commissioner, 74 T.C. 305 (1980), aff'd per curiam, 671 F.2d 316 (9th Cir.), cert. denied, 103 S. Ct. 211 (1982). Cf. Del Cotto, Sale and Leaseback: A Hollow Sound When Tapped?, 37 Tax L. Rev. 1 (1981) (suggesting characterization as sale of future interest). However, carefully structured sale-leaseback financing techniques that take advantage of the tax benefits of real property ownership were available under the Code before the Economic Recovery Tax Act of 1981, Pub. L. No. 97-34, 97th Cong., 1st Sess., § 201, 95 Stat. 172 (codified as amended at I.R.C. $\$ 168(\mathrm{~F})(8)$ (Supp. VI 1982), authorized "safe harbor" leasing, and probably will be available after the repeal of "safe harbors" by the Tax Equity and Fiscal Responsibility Act of 1982, Pub. L. No. 97-248, § 209, 96 Stat. 442 (to be codified at I.R.C. $\$ 168(F)(8)$ ). See generally Harmelink \& Shurtz, Sale-Leaseback Transactions Involving Real Estate: A Proposal for Defined Tax Rules, 55 So. Cal. L. Rev. 833 (1982); Equipment Leasing, Tax Mgmt. (BNA) No. 12-5th, at A-44 (1982).

27. Nonparallel accounting methods in a sale-leaseback transaction (i.e., an accrual method seller-lessee and a cash method buyer-lessor) may raise an intuitive objection, since the accrual method taxpayer may get a deduction before the cash method taxpayer reports income. The Code, however, cannot both allow different methods of accounting (as it does in § 446(c)) and avoid having nonparallel accounting methods applied tó some transactions. Whenever a cash method taxpayer does business with an accrual method taxpayer, each will treat the transaction differently, to the possible detriment of the Treasury. The Code addresses this problem for transactions between related taxpayers, where the deduction is denied to the accrual method taxpayer unless the related taxpayer reports the income within $2 \frac{1}{2}$ months after the close of the deduction year. I.R.C. $\$ 267(a)(2)$ (1976). The seller and buyer in a sale-leaseback transaction, however, would not be considered "related" under $\S 267$. No case has expanded the statutory rule to require parallel accounting in the sale-leaseback context. Compare $\S 267$ with Alstores Realty Corp. v. Commissioner, 46 T.C. 363 (1966), and Steinway \& Sons v. Commissioner, 46 T.C. 375 (1966) (companion cases) (tax court relied on stare decisis to require the same accounting characterization by both accrual method parties to a property transfer). Cf. Treas. Reg. $\S 1.991-1$ (1974) (barring nonparallel accounting for controlled group domestic international sales corporations).

28. Through careful phrasing of the lease terms, the accrual can probably be made to meet the "all events" test. Current accruals based on an aliquot (ratable) allocation of total payments due under a lease providing for low initial and high subsequent cash payments have been upheld in non sale-leaseback contexts. Grand Ave. Motor Co. v. United States, 124 F. Supp. 423 (D. Minn. 1954); Rev. Rul. 70-119, 1970-1 C.B. 120. Cf. Consolidated Foods Corp. v. Commissioner, 66 T.C. 436, 443 (1976) (ratable deductions of payments due are proper, but current credit against payment is not ratable under tax benefit rule). In Grand Avenue, the taxpayer, an auto dealer, had a lease that provided for a payment reduction during wartime production cutbacks, the reduction to be made up in increased rent payments when full production was resumed. The taxpayer was allowed to take an accrued deduction for deferred rent even though it was not to be paid for several years. Compare Grand Avenue (low-high rentals accruable) with Rev. Proc. 7521, 1975-1 C.B. 715, § 5.01 (Internal Revenue Service (IRS) indicates it will challenge leaseback 
based on the future rather than present value of the deferred payments.) The tax savings of this deferral ${ }^{29}$ become part of the tax value of the sale-leaseback transaction and are shared by the participants through adjustments in the transaction terms.

Another manipulation of accrual accounting's failure to recognize the time value of deferral can be seen in recently proposed schemes to accrue nonamortizing loan interest on the basis of the "Rule of 78s." 30 The Rule of $78 \mathrm{~s}$ applies to the portion of a loan obligation treated as prepaid interest and thus not disbursed to the borrower in cash. This "prepaid interest," which has not in fact been "prepaid" since no cash has left the borrower's hands, is deducted as an expense over the life of the loan. Under the Rule of 78s method of allocation, larger amounts are allocated as an expense to earlier periods (compared with straight line amortization) and smaller amounts are written off later. ${ }^{31}$ The use of Rule of $78 \mathrm{~s}$ accounting has been approved in revenue

low-high rent payments in excess of certain limits, though the IRS does not indicate whether the challenge would be to force the lessor to recognize the deferred income currently, or force the lessee to defer the deduction).

Despite these authorities, an argument can be made that lease payments ought not to be accruable before payable, as contingent unmatured contractual obligations that do not meet the "all events" test. Cf. Lucas v. American Code Co., 280 U.S. 445 (1930) (breach of contract does not satisfy "all events" for accrual since payment is contingent on duty to mitigate damages); Levin v. Commissioner, 219 F.2d 588 (3d Cir. 1955) (contract obligations not accruable at signing; contingent on return performance); Colloids, Inc. v. Manning, 138 F. Supp. 162 (D.N.J. 1955) (same). The "contingency" of the lease payment due depends, however, on the treatment of the lease under state law, on the phrasing of the lease, and possibly on the requirement that lessor mitigate damages in the event of a breach by lessee. This is a developing area of property law and only a minority of jurisdictions have such a duty to mitigate. See Annot., 21 A.L.R.3d 534 (1968).

The regulations seem to take the opposite approach. They treat a lease as a conveyance rather than as a contract subject to constructive conditions. Thus, under Treas. Reg. $\$ 1.162-11$ (a) (1958), a purchased leasehold may be amortized ratably over the life of the lease; while the "all events" test of Treas. Reg. § 1.461-1(a) (1957) for all payments to become due may be satisfied upon signing the lease, such payments are not immediately deductible because "an asset having a useful life which extends substantially beyond the close of the taxable year" is created and must be capitalized under Treas. Reg. $\S 1.461-1(\mathrm{a})(2)$. The ratable deduction under $\S 1.162-11$ (a) will equal the yearly payments under a flat rate lease, but will be substantially greater than the yearly payments early in the lease under a low-high uneven payment lease. Thus the regulations seem to support the accrual that the seller-lessee will be seeking. To be safe under the "all events" test, however, the seller-lessee would probably desire a lease clause making liability for the deferred portion of the rent absolute as soon as each period ends and providing for payment of all deferred rent in case of termination for any reason.

29. These tax "savings" might be variously determined. One approach is to view the difference between the present value of the future net payment and the accrued amount as a "phantom" deduction, yielding savings at the marginal rate of the lessee taxpayer. Another approach is to view the entire deduction as accelerated and compute the deferral value of the tax thus delayed. The former approach might be more accurate since it takes some account of the detriment to current taxpaying ability of a future liability. The second approach more closely approximates cash accounting treatment.

30. Cohen, Rule of 78s Interest Accrual: An Outline of Tax Considerations, in 2 Real Estate Syndications, P.L.I. Course H.B. No. 213, at 289 (1982); Glickman, Rule of 78s Interest Deductions, in id. at 271.

31. The Rule of 78s is a sum-of-the-months' digits method of amortization. For a one-year loan, each month's allocated portion of prepaid interest would be computed by taking a fraction whose numerator is the number of months left to run and whose denominator is 78 (the sum of 
rulings ${ }^{32}$ in the context of principal amortizing loans where the loan agreement provides for a prepayment interest rebate according to the Rule of 78s. In this context, the Rule of $78 \mathrm{~s}$ amortization approximates a loan amortization schedule in that the early interest payments are higher, reflecting the higher principal balance.

Even in a flat interest payment nonamortizing loan (where the principal is due in a balloon payment at the end), however, the parties may agree to a prepayment penalty based on a Rule of $78 \mathrm{~s}$ allocation of the total interest to be earned under the agreement. By allocating a larger portion of the interest to early periods even though the principal balance is constant, this Rule of $78 \mathrm{~s}$ allocation does not approximate the real interest rate. But, since this liability matures at the close of each period, the "all events" test of accrual accounting would be met. ${ }^{33}$ Such an agreement would attempt to accelerate the deduction for interest, yielding a tax deferral benefit. ${ }^{34}$ If the lender is cash method or tax-exempt, ${ }^{35}$ such a clause can only benefit it by providing for a high prepayment penalty. Like the rent deferral, this early accrual at full value defeats horizontal equity, since the transaction is essentially the same as a loan at flatrate interest payments, for which the borrower would not get such accelerated deductions. ${ }^{38}$

Courts have never explicitly recognized this susceptibility of accrual accounting to abuse by exploiting the time value of a distant obligation. The Fifth Circuit approached but did not identify the present value issue in Mooney Aircraft, Inc. v. United States. ${ }^{37}$ There, the court upheld the Commissioner's section 446(b) "clearly reflect income" disallowance of an accrual where the time between accrual and payment, according to the court, was "too long." 38 Mooney concerned the current accrual of a deduction for

the numbers one through twelve). Thus, the first month's portion would be $12 / 78$, which is greater than the $1 / 12$ allocation of straight-line amortization. The next month's allocation is $11 / 78$, then 10/78, and so on. See generally Glickman, supra note 30 .

32. Rev. Rul. 72-100, 1972-1 C.B. 122; Rev. Rul. 74-395, 1974-2 C.B. 46.

33. The workings of this Rule of 78 s allocation can be illustrated by a loan of $\$ 100$ at $10 \%$ interest for two years, with the principal due in full at the end of the two years. Each year the borrower actually pays $\$ 10$ to the lender. The loan agreement, however, allocates the $\$ 20$ total interest (\$10 per year for the two years) according to the Rule of $78 \mathrm{~s}$, so that in the first year $\$ 14$ of interest would be considered earned (determined by dividing 202, the sum of the remaining months' digits-24 through 13-by 280 , the sum of the digits of the 24 months in the two years, and multiplying the result by $\$ 20$, the total interest charge on the loan). This $\$ 14$ interest allocated to the first year is greater than the $\$ 10$ interest actually paid and normally allocated. The borrower would be legally obligated to pay this $\$ 14$ at the end of the first year should the loan be prepaid at that time. But this penalty would not deter a borrower willing to forgo the ability to terminate the loan early in return for the tax advantages. The deferral results are more dramatic when the loan period is increased.

34. It might be said that liability is contingent on prepayment and thus not accruable. If this is perceived as a problem, the agreement can easily be drafted so that the Rule of 78 s liability is absolute at the close of each period, the only contingency being as to the time of payment.

35. Pension funds and life insurance companies, for example, are tax-exempt sources of such financing.

36. The borrower may be said to have given up some taxpaying ability by agreeing to the prepayment penalty.

37. 420 F.2d 400 (5th Cir. 1969).

38. Id. at 410. 
"bonds" given to the purchaser of the taxpayer's aircraft. These bonds were redeemable for $\$ 1,000$ when the aircraft was retired. The manufacturer accrued a deduction for the entire $\$ 1,000$ in the year of sale. The Fifth Circuit found that the "all events" test was satisfied, since the eventual retirement of the aircraft was inevitable. ${ }^{39}$ The court went on to find, however, that the remoteness of payment warranted disallowance of the accrual under section 446(b). In elaborating the reasons why remoteness of payment barred accrual as a distortion of income, the court focused on the taxpayer's liquidity ${ }^{40}$ and the diminished likelihood of payment. ${ }^{41}$ The Mooney court did not articulate the factor that the present value of an obligation to be paid in twenty years was much diminished. One suspects, however, that a sense of this problem contributed to the court's discomfort with the current accrual of such a remote payment. ${ }^{42}$

The Mooney case, disallowing accrual accounting in a particular situation, and the Burck case, similarly disallowing cash accounting, suggest a legal approach that would enable the Commissioner to defeat accounting manipulations. In both cases, the circuit courts relied on the section 446(b) "clearly reflect income" test to disallow an accounting method otherwise authorized in section 446(c). The courts also relied on the evolving rule that the Commissioner has discretion to determine whether a particular application of an accounting method clearly reflects income. Both courts applied a relaxed standard of review in scrutinizing the Commissioner's determinations to disallow the accounting methods at issue.

Though both cases applied a relaxed standard of review to the Commissioner's determination, no case under section $446(\mathrm{~b})$ has interpreted the nature of the Commissioner's discretion or the content of the "clearly reflect in-

39. Id. at 406.

40. Id. at $409-10$.

41. Id. at 410. Cf. Fahs v. Martin, 224 F.2d 387 (5th Cir. 1955) (unlikelihood of payment does not bar accrual); Zimmerman Steel Co. v. Commissioner, 130 F.2d 1011 (8th Cir. 1942) (same). The Mooney court called the rule in these cases "dubious ... in light of Schlude and $A A A . " 420$ F.2d at 410 n.38. See generally discussion of Schlude v. Commissioner, 372 U.S. 128 (1963) and American Automobile Ass'n v. United States, 367 U.S. 687 (1961), infra text accompanying notes $133-43$.

42. See the Mooney court's langauge in discussing the liquidity aspect:

In this case . . . the related expenditure is so distant from the time the money is received as to completely attenuate any relationship between the two. For all practical purposes the revenue taxpayer received from the sale of the planes is his to use as he pleases. Rather than being set up as a reserve . . . it is far more probable that the money will be used as capital to expand the business.

420 F.2d at 409-10. See A. Gunn, Federal Income Taxation Cases and Other Materials 662 (1981) (noting the present value aspect of Mooney).

There may also be an economic efficiency aspect to the Mooney case. The "Mooney bonds" were a real reduction in the price of the aircraft, and if the amount of the reduction was based in part on the manufacturer's expected tax benefit from immediate deduction, the price reduction may have been uneconomical. If Mooney invested the $\$ 500$ tax reduction (assuming a $50 \%$ bracket), the fund thus created would more than cover the cost of redeeming the bonds over normal airplane life. Mooney thus gets a "free" price advantage, distorting the market for aircraft. 
come" test in such a way that disallowance of manipulative accrual accounting could be predicted with confidence. A court might limit Burck to cash accounting abuse. ${ }^{43}$ The Mooney holding that time for payment was "too long" rested on the shaky grounds of taxpayer liquidity and diminished likelihood of eventual payment. Extension of these cases to the disallowance of the accrual manipulations discussed earlier depends on the nature of the Commissioner's discretion under section $446(\mathrm{~b})$, the content of the "clearly reflect income" test, and the relationship between the two. If the defeat of tax equity inherent in these accrual schemes can be the basis for the Commissioner's exercise of discretion to disallow an accounting method, the Commissioner may successfully thwart them.

\section{Commissioner's Discretion to Determine Whether Income is Clearly Reflected}

The decision of whether the Commissioner has discretion to disallow accounting methods that do not clearly reflect income is essentially a decision as to whether the Commissioner or the courts should have determinative power to interpret section 446. A determination that an accounting method does not "clearly reflect income" would seem to be a decision of a mixed question of law and fact. ${ }^{44}$ Evidentiary and historical facts usually are not disputed in this context; ${ }^{45}$ determination of the question usually depends on the legal construction of the statutory language as applied to particular facts. ${ }^{46}$

While it is often said in the context of judicial review of such "mixed questions" that courts decide the law and agencies decide the facts, it is seldom easy to separate the two. ${ }^{47}$ For this reason, commentators have discounted the importance of the law-fact distinction and the bar against agency discretion to make "legal" determinations. ${ }^{48}$ Professor Davis has suggested that the judicial parsing of the law-fact distinction is actually a determination of whether the matter is appropriate for agency discretion. ${ }^{49}$ Professor Jaffe

43. See discussion of judicial attitudes towards cash accounting infra note 163.

44. Cf. Madison Gas \& Elec. v. Commissioner, 72 T.C. 521, 555 (1979) ("primarily a question of fact"), aff'd, 633 F.2d 512 (7th Cir. 1980); Peninsula Steel Prods. \& Equip. v. Commissioner, 78 T.C. 1029, 1045 (1982) (same). See generally K. Davis, Administrative Law Text 545-56 (3d ed. 1972).

45. Cf. American Automobile Ass'n v. United States, 367 U.S. 687, 691 (1961) (rejecting attempt to distinguish on basis of different proof); RCA Corp. v. United States, 664 F.2d 881, 882 (2d Cir. 1981), cert. denied, 102 S. Ct. 2958 (1982) (\$ 446(b) case "tried largely on a stipulated record, and the facts are substantially undisputed").

46. Cf. L. Jaffe, Judicial Control of Administrative Action 569-75 (1965) (application of construction of statutory language to fact; argument for extension of agency discretion to legal interpretation of statutory language).

47. See K. Davis, supra note 44 , at 545-56.

48. See generally Monaghan, Marbury and the Administrative State, 83 Colum. L. Rev. 1, 4, 25-31 (1983) (rejecting distinction between determination of mixed question and agency rulemaking).

49. See K. Davis supra note 44, at 545-56. 
has urged that agency discretion be extended to legal determinations not contrary to the "clear purpose" of the statute. ${ }^{50}$ It follows that the relevant characterization of the section $446($ b) "clearly reflect income" determination is not whether it is "law" or "fact," but rather whether the discretion to apply the "clearly reflect income" test, which has a legal dimension, has been granted to the Commissioner. The central question, then, is whether Congress intended in section 446 to grant this discretion to the Commissioner.

\section{A. Source of Discretion: Thor Power Tool}

The Supreme Court's reaffirmation, in Thor Power Tool Co. v. Commissioner, ${ }^{51}$ that the Commissioner has discretion to determine whether or not an accounting method employed by a taxpayer clearly reflects income is apparently a little-noted recent development in the law. ${ }^{52}$ Such discretion is not compelled by a literal reading of section $446(\mathrm{~b})$, which provides, "[i]f no method of accounting has been regularly used by the taxpayer, or if the method used does not clearly reflect income, the computation of taxable income shall be made under such method as, in the opinion of the Secretary, does clearly reflect income." 53 Though the Commissioner (as delegate of the Secretary) ${ }^{54}$ is assigned the task of choosing the accounting method to be used if the taxpayer's method does not clearly reflect income, the wording of the statute does not require that the Commissioner make the initial determination of whether or not a particular accounting method clearly reflects income. The statutory language could be read as leaving that determination to the courts.

50. See L. Jaffe, supra note 46 at 569-75. Cf. Monaghan, supra note 48, at 25-31 (delegation of lawmaking discretion constitutionally permissible).

51. 439 U.S. 522 (1979).

52. The Thor case is discussed in Bush, Flannery, \& Dasburg, IRS's Tough New Rules Under Thor Power: How They Work; What They Mean, How to Cope, 52 J. Tax'n 194 (1980); Dasburg, Porche, \& Flannery, Inventory Valuation After Thor Power Tool: Analyzing the S. Ct. Decision and its Impact, 50 J. Tax'n 200 (1979); Young, Supreme Court Report, 65 A.B.A. J. 448, 462 (1979); Mihalov, Inventory Write-Downs and Thor Power Tool, 57 Taxes 384 (1979); Sutherland, Tax Treatment of Inventory Write-Downs after Thor Power Tool, 29 Tul. Tax Inst. 9 (1980); Note, Generally Accepted Accounting Principles as a Reflection of Income: Thor Power Tool Company v. Commissioner of Internal Revenue, 9 Cap. U.L. Rev. 775 (1980) [hereinafter cited as Note, Generally Accepted Accounting]; Note, Thor Power Tool Co. v. C.I.R. Further Erodes C.P.A.'s Defense of Observing Professional Standards, 19 Am. Bus. L.J. 87 (1981). Of these treatments, only Dasburg, Porche, \& Flannery, supra, at 202-03, and Note, Generally Accepted Accounting, supra, at 782-84, consider the scope of the Commissioner's discretion. Neither treats the subject in depth.

Several circuit court cases dealing with $\S 446$ (b) determinations do not even cite Thor. E.g., Ferrill v. Commissioner, 684 F.2d 261, 263 (3rd Cir. 1982); NCNB Corp. v. United States, 651 F.2d 942, 953 (4th Cir. 1981), vacated on reh'g, 684 F.2d 285 (4th Cir. 1982) (no discussion of discretion issue). The $N C N B$ court seems to have read Thor, since their reasoning that tax accounting and financial accounting have different goals closely tracks that of the Thor Court. Compare $N C N B, 651$ F.2d at 955 , with Thor, 439 U.S. at 542.

53. I.R.C. \& 446(b) (1976) (emphasis added).

54. The Code, id. $\S 7701$ (a)(11)(B) (1976), defines "Secretary" as "Secretary of the Treasury or his delegate." 
The legislative histories of section $446(b)^{55}$ and its predecessors ${ }^{56}$ are at best ambiguous on the question of who shall make the "clearly reflect income" determination. ${ }^{57}$ Treasury regulations promulgated under the predecessors to section $446(\mathrm{~b})$ were essentially neutral on the question..$^{58}$ When

55. I.R.C. $\S 446($ b) is discussed in H.R. Rep. No. 1337, 83d Cong., 2d Sess. A157-58, reprinted in 1954 U.S. Code Cong. \& Ad. News 4017, 4296-97 [hereinafter cited as House Report]; S. Rep. No. 1622, 83d Cong., 2d Sess. 299-300, reprinted in 1954 U.S. Code Cong. \& Ad. News 4621, 4939-40 [hereinafter cited as Senate Report]. The Tax Reform Act of 1976, Pub. L. No. 94-455, § 1906(b)(13)(A), 90 Stat. 1520, 1834, (codified at I.R.C. § 446(b) (Supp. I 1977)) amended $\S 446$ (b) by substituting "Secretary" for "Secretary or his delegate." At the same time, the Tax Reform Act amended I.R.C. § 7701 to define "Secretary" as "Secretary of the Treasury or his delegate." Id. at § 1906(a)(57)(A) (codified at I.R.C. § 7701(a)(11)(b) (Supp. I 1977)).

56. The requirement that a tax accounting method "clearly reflect income" first appeared in the Revenue Act of 1916:

[A] corporation, joint stock company or association, or insurance company, keeping accounts upon any basis other than that of actual receipts and disbursements, unless such other basis does not clearly reflect its income, may, subject to regulations made by the Commissioner of Internal Revenue ... make its return upon the basis upon which its accounts are kept ....

Revenue Act of 1916, ch. 463, § 13(d), 39 Stat. 756, 771 (repealed 1918) (emphasis added). Cf. id. $\S 8(\mathrm{~g})$ (similar language applied to individuals). Section 13(d) is considered in H.R. Rep. No. 922, 64th Cong., 1st Sess. 4 (1916); H.R. Rep. No. 1200, 64th Cong., 1st Sess. 28 (1916); J.S. Seidman, Seidman's Legislative History of Federal Income Tax Laws 1938-1861, at 974 (1938) (statement of R.R. Reed at Senate Finance Committee Hearing) [hereinafter cited as J.S. Seidman I].

The Revenue Act of 1918's analogous section read:

The net income shall be computed upon the basis of the taxpayer's annual accounting period .... in accordance with the method of accounting regularly employed in keeping the books of such taxpayer; but if no such method of accounting has been so employed, or if the method employed does not clearly reflect the income, the computation shall be made upon such basis and in such manner as in the opinion of the Commissioner does clearly reflect the income.

Revenue Act of 1918, ch. 18, § 212(b), 40 Stat. 1057, 1064-65 (repealed 1921) (emphasis added). This section is considered in H.R. Rep. No. 1037, 65th Cong., 3d Sess. 47 (1917) (amendment a "clerical change"); Hearings Before the Senate Finance Comm. 23 (1917) (statement of A.E. Holcomb). See J.S. Seidman I, supra, at 903.

The Internal Revenue Code of 1939 essentially adopted the 1918 Act $\S 212$ (b) language in haec verba without any comment in committee reports. Internal Revenue Code of $1939, \mathrm{ch} .2, \S$ 41, 53 Stat. 1, 24 (repealed 1954). See 1 J.S. Seidman, Seidman's Legislative History of Federal Income Tax and Excess Profits Tax Laws 1953-1939, at 1460 (1954).

57. While the committee reports on the various "clearly reflect income" provisions repeat the statutory langauge, none considers who shall make the determination. See the committee reports cited supra notes $55 \& 56$.

The original 1916 bill, as introduced, H.R. 16763, 64th Cong., 1st Sess., reprinted in S. Doc. 531, 64th Cong., 1st Sess. 35 (1916), read "unless the Commissioner of Internal Revenue finds that such other basis does not clearly reflect his income." Id. (emphasis added). The italicized language was dropped by the Senate in the final bill. The only inference that can be drawn from this change works against the existence of Commissioner discretion to determine whether income is clearly reflected. The conference committee report, however, referred to the change as "clerical" and did not discuss it. H.R. Rep. No. 1200, 64th Cong., 1st Sess. 28 (1916). See J.S. Seidman I, supra note 56, at 974 .

58. Treas. Regulations No. 33 (1913), promulgated under the Revenue Act of 1916, ch. 463, 39 Stat. 756 (repealed 1918), does not refer to the "clearly reflect income" standard. Treas. Regulations No. 45 (1919), promulgated under the Revenue Act of 1918, ch. 18, 40 Stat. 1057 (1919) (repealed 1921), provides in article 22 that:

The time as of which any item of gross income or any deduction is to be accounted for must be determined in the light of the fundamental rule that the computation shall be made in such a manner as clearly reflects the taxpayer's income. If the method of accounting regularly employed by him in keeping his books clearly reflects his income, it is to be followed .... . 
regulations were first issued under section $446(\mathrm{~b})$ of the 1954 Code, ${ }^{50}$ despite the adoption in haec verba of the "clearly reflect income" formulation of the 1939 Code, ${ }^{60}$ Regulations section 1.446-1(a)(2) asserted that "no method of accounting is acceptable unless, in the opinion of the Commissioner, it clearly reflects income." language led one early commentator, who maintained that the burden of showing that income was not clearly reflected was on the Commissioner, ${ }^{02}$ to refer to section 1.446-1(a)(2) as one of the "conflicting provisions of the present regulations, which presumably would be held to be invalid." 63

In Thor Power Tool Co. $v$. Commissioner, ${ }^{84}$ the Supreme Court stated:

It is obvious that on their face, $\S \$ 446$ and 471 , with their accompanying Regulations, vest the Commissioner with wide discretion in determining whether a particular method of inventory accounting should be disallowed as not clearly reflective of income. This Court's cases confirm the breadth of this discretion. ${ }^{05}$

Thor involved the inventory accounting method used by a tool manufacturer. The manufacturer intentionally produced more replacement parts for discontinued models than its estimate of demand, in order to avoid retooling costs should demand exceed the estimate. ${ }^{66}$ The manufacturer then wrote down this excess inventory to scrap value ${ }^{67}$ essentially taking a current deduction for the manufacturing cost of items remaining in its inventory. This practice was in accordance with generally accepted accounting principles (GAAP), ${ }^{68}$ but was contrary to the inventory accounting methods prescribed by the regulations. ${ }^{00}$ Adopting a standard of review that would require the taxpayer to demonstrate "clearly unlawful"71 or "plainly arbitrary"72 abuse of discretion, the

Treas. Regulations No. 45, supra, at 18 . In article 23 , these regulations provided that "[a]pproved standard methods of accounting will ordinarily be regarded as clearly reflecting income. A method of accounting will not, however, be regarded as clearly reflecting income unless all items of gross income and all deductions are treated with reasonable consistency." Id. While these regulations thus form a test for "clearly reflect income," they do not claim Commissioner discretion to apply the test. This 1920 formulation was adopted for the regulations right up through the 1939 code. See Treas. Regulations No. 103, $\S 1941-1$ to -2 (1940).

59. Treas. Reg. \& 1.446-1, T.D. 6282, 1958-1 C.B. 215, 217 (1957).

60. Section 41 of the 1939 Code read: "if no such method of accounting has been so employed, or if the method employed does not clearly reflect the income, the computation shall be made in accordance with such method as in the opinion of the Commissioner does clearly reflect the income." Internal Revenue Code of 1939, ch. 2, § 41, 53 Stat. 1, 24 (repealed 1954).

61. Treas. Reg. § 1.446-1 (1957).

62. Graves, Limitations on Commissioner's Power to Require Accounting Changes, 19 N.Y.U. Tax Inst. 1209, 1212 (1961) ("Unless the Commissioner can demonstrate that the method he seeks to change does not reflect income he has substantially no basis on which to proceed.").

63. Id. at 1219.

64. 439 U.S. 522 (1979).

65 . Id. at 532 .

66. Id. at $525-26$.

67. Id. at 527 .

68. Id. at 530 .

69. Id. at 533-35; Treas. Reg. §§ 1.471-2, -4 (1958).

70. 439 U.S. at $532,538$.

71. Id. at 532 (quoting Lucas v. American Code Co., 280 U.S. 445, 449 (1930)).

72. Id. at 533 (quoting Lucas v. Structural Steel Co., 281 U.S. 264, 271 (1930)). 
Court found disallowance of the taxpayer's method to be a proper exercise of the Commissioner's discretion. ${ }^{73}$

Since section 471 of the Code explicitly grants discretion to the Commissioner in prescribing inventory accounting methods that clearly reflect income,$^{74}$ the Court's remarks concerning discretion under section 446 may be dictum. The Court considered section 446 in response to the taxpayer's assertion that under the section 446 regulations, ${ }^{75}$ an accounting method in accordance with GAAP is presumptively valid as a clear reflection of income. ${ }^{76} \mathrm{By}$ rejecting this assertion, the Court might only be holding that the presumption of validity under section 446 is limited by specific regulations under the discretion explicitly granted by section $471 .{ }^{77}$ Thor can, however, be read more broadly, as suggested by the Court's "obvious ... on their face" language, to hold that the presumptive validity of GAAP, implicit in section 446 of the statute, ${ }^{78}$ is limited by the Commissioner's discretion to reject an accounting method, which discretion the Court also found in section 446 of the statute. ${ }^{79}$

73. Id. at 537-38.

74. § 471 provides:

Whenever in the opinion of the Secretary the use of inventories is necessary in order clearly to determine the income of any taxpayer, inventories shall be taken by such taxpayer on such basis as the Secretary may prescribe as conforming as nearly as may be to the best accounting practice in the trade or business and as most clearly reflecting the income.

I.R.C. $\$ 471$ (1976).

75. $\S 1.446-1(a)(2)$ provides that "[a] method of accounting which reflects the consistent application of generally accepted accounting principles in a particular trade or business in accordance with accepted conditions or practices in that trade or business will ordinarily be regarded as clearly reflecting income . . . " Treas. Reg. § 1.446-1(a)(2) (1957).

76. Thor, 439 U.S. at 538.

77. See the Court's language in Thor:

If the Code and Regulations did embody the presumption [in favor of GAAP] that petitioner postulates, it would be of little use to the taxpayer in this case. As we have noted, Thor's write-down of "excess" inventory was inconsistent with the Regulations; any general presumption obviously must yield in the face of such particular inconsistency.

Id. at 540 .

78. § 446(a) of the 1954 Code states the general rule that "[t]axable income shall be computed under the method of accounting on the basis of which the taxpayer regularly computes his income in keeping his books." I.R.C. § 446(a) (1976). The regular method of a business taxpayer will usually be according to GAAP. The House Committee on Ways and Means Report on the 1954 Code states: "A method of accounting which reflects the consistent application of generally accepted accounting principles in a trade or business will ordinarily be considered as clearly reflecting income." House Report, supra note 55, at A157-58, reprinted in 1954 U.S. Code Cong. \& Ad. News 4017, 4296. The Senate Finance Committee report uses the same language. Senate Report, supra note 55, at 299-300, reprinted in 1954 U.S. Code Cong. \& Ad. News $4621,4939$.

79. The $\S 446(\mathrm{~b})$ "clearly reflect income" test is labeled as an exception to the $\S 446$ (a) authorization of book accounting methods. I.R.C. \$ 446(b) (1976). Cf. Thor, 439 U.S. at 532 (broad discretion on face of $\S 446(b)$ ); Lucas v. American Code Co., 280 U.S. 445, 449 (1930) ("clearly reflect income" expressly limits book method); A. Marrs, Revenue Bill of 1954, at 21 (1953) ("recurring attempts" of accounting profession to make GAAP presumptively valid limited by "clearly reflect income" test). 
The cases cited by the Thor Court ${ }^{80}$ in support of broad Commissioner discretion under section 446 all suffer from a similar ambiguity. While each case cited contains explicit language in support of Commissioner discretion under section 446 to determine whether income is clearly reflected, ${ }^{81}$ each case may also be distinguished as involving a different question. The cases might be seen as decisions on the proper application of the accounting method used rather than on the propriety of using the accounting method in particular circumstances. ${ }^{82}$

Thus, the discussion of Commissioner discretion in these cases may not have been required by the facts before the courts. But by claiming to adopt the relaxed abuse of discretion standard of review, these cases ought to be read as support, though hardly "obvious," for the proposition that Commissioner discretion does exist under section 446. If these $\operatorname{cases}^{83}$ did not, in fact,

80. The Thor Court cites United States v. Catto, 384 U.S. 102 (1966); Schlude v. Commissioner, 372 U.S. 128 (1963); American Automobile Ass'n v. United States, 367 U.S. 687 (1961); Commissioner v. Hansen, 360 U.S. 446 (1959); Automobile Club v. Commissioner, 353 U.S. 180 (1957); Brown v. Helvering, 291 U.S. 193 (1934); Lucas v. American Code Co., 280 U.S. 445 (1930). Thor, 439 U.S. at 532.

81. United States v. Catto, 384 U.S. 102, 114 (1966) ("Congress has granted the Commissioner broad discretion in shepherding the accounting methods used by taxpayers ...."); Schlude v. Commissioner, 372 U.S. 128, 133 (1963) ("the Commissioner, exercising his discretion under § 41, 1939 Code, and § 446(b), 1954 Code" (footnotes omitted)); American Automobile Ass'n v. United States $(A A A), 367$ U.S. 687, 697-98 (1961) ("[f]inding only that . . . the exercise of the Commissioner's discretion in rejecting the ... accounting system was not unsound"); Commissioner v. Hansen, 360 U.S. 446, 467 (1959) ("The Commissioner has broad powers in determining whether accounting methods used by a taxpayer clearly reflect income . . . ."); Automobile Club of Michigan v. Commissioner (Michigan), 353 U.S. 180, 189-90 (1957) ("Section 41 vests the Commissioner with discretion to determine whether the petitioner's method of accounting clearly reflects income. We cannot say, in the circumstances here, that the discretionary action of the Commissioner . . . exceeded permissible limits."); Brown v. Helvering, 291 U.S. 193, 203 (1934) ("[i]f in the opinion of the Commissioner it does not clearly reflect the income"); Lucas v. American Code Co., 280 U.S. 445, 449 (1930) ("[T]he direction that net income be computed according to the method of accounting regularly employed by the taxpayer is expressly limited to cases where the Commissioner believes that the accounts clearly reflect the net income. Much latitude for discretion is thus given ....").

82. It is possible to distinguish an error in the application of an acceptable accounting method from the use of an accounting method which does not clearly reflect income in particular circumstances. Cf. Life Ins. Co. v. United States, 650 F.2d 250, 256 (Ct. Cl. 1981) ("We are not dealing with issues of abuse of discretion, but, rather, the interpretation of the all events test."); O Liquidating Corp. v. Commissioner, 19 T.C.M. 154 (1960) (correction of error not change in method); Graves, supra note 62, at 1210 (necessary to distinguish between correction and change). With this distinction in mind, American Code Co. and Brown, both of which concerned attempts to accrue deductions before the "all events" test for accrual deductions was satisfied (Treas. Reg. $\S 1.461-1(a)(2)$ (1957)) by setting up accounting reserves, can be seen as erroneous applications of an acceptable accounting method. AAA, Michigan, Hansen, and Schlude can similarly be viewed as decisions concerning the proper time for recognizing income under an accrual accounting system, rather than as a Commissioner disallowance of the unchallenged rules of an accounting method.

Catto, the remaining cited case, does not require Commissioner discretion to disallow accounting methods under $\S 446(\mathrm{~b})$. In Catto, a rancher sought to avoid the inclusion of breeding stock in inventory as required by Treas. Reg. $\$ 1.471-6(f) .384$ U.S. at 108-09 (1966). Since $\$ 471$ of the 1954 Code explicitly grants discretion to the Commissioner, supra note 74 , the Catto decision under that provision does not require an "abuse of discretion" standard under $\S 446$ (b).

83. With the exception of Catto. See discussion of cases supra note 82. 
consider the issue to be the acceptability of a particular accounting method, there would be no need to enunciate the "clearly reflect income" test, nor would a relaxed standard of review be applicable. The court would simply consider the principles for applying the accounting method in question to determine whether it was erroneously applied. ${ }^{84}$

The broader reading of the Thor holding has been adopted by the First, Second, and Eighth Circuits in evaluating challenges to accounting methods under section 446(b).$^{85}$ The Second Circuit, in RCA Corp. v. United States, ${ }^{86}$ cited Thor for the proposition that "[i]t is well established that the Commissioner enjoys 'broad discretion' to determine whether, 'in [his] opinion,' a taxpayer's accounting methods clearly reflect income." ${ }^{87}$ Similarly, the Eighth Circuit, in Record Wide Distributors, Inc. v. Commissioner, ${ }^{88}$ cited Thor in support of the Commissioner's "broad discretion to evaluate and modify a taxpayer's accounting method in order to insure the clear reflection of income." ${ }^{89}$ In Bay State Gas Co. v. Commissioner ${ }^{80}$ the First Circuit also cited Thor in support of both the Commissioner's "broad discretion" to make the section 446(b) determination and a relaxed standard of review of such a determination. ${ }^{91}$ These opinions neither attempted to limit the Thor Court's language as dictum, nor distinguished the earlier cases as involving errors of accounting application. These cases, combined with the Thor Court's conclusory citation of the prior Supreme Court cases, would seem to settle the question of the existence of Commissioner discretion under section 446(b).

Moreover, determining the acceptability of a method of tax accounting is an appropriate matter for agency discretion. If one accepts that "[it] is not the province of the court to weigh and determine the relative merits of systems of accounting," 92 and that "no uniform method of accounting can be prescribed

84. Cf. Life Ins. Co. v. United States, 650 F.2d 250, 256 (Ct. Cl. 1981) ("We are not dealing with issues of abuse of discretion, but, rather, the interpretation of the all events test."). However, the Commissioner's power to disallow an accounting method as applied to only one item while requiring retention of the overall accounting method, upheld in United States v. American Can Co., 280 U.S. 412 (1930); Anderson v. Commissioner, 568 F.2d 386, 388-89 (5th Cir. 1979); Sandor v. Commissioner, 536 F.2d 874, 875 (9th Cir. 1976), vitiates this distinction between erroneous application and improper method. The American Code and Brown decisions can as easily be viewed as concerning questioned accounting methods (setting up reserves) as they can be viewed as concerning the erroneous applications of accrual accounting (timing of deductions for underlying expenses).

85. Cf. Frysinger v. Commissioner, 645 F.2d 523 (5th Cir. 1981) (discretion acknowledged but limited by specific regulations).

86. 664 F.2d 881 (2d Cir. 1981), cert. denied, 102 S. Ct. 2958 (1982).

87. Id. at 886 .

88. 682 F.2d 204 (8th Cir. 1982), cert. denied, 51 U.S.L.W. 3552 (U.S. Jan. 25, 1983) (No. 82-868).

89. Id. at 206.

90. 689 F.2d 1 (1st Cir. 1982).

91. Id. at 4. The court went on to reject the Commissioner's challenge, finding his distinction requiring different accounting treatment of similar events "not rational." Id. at 7.

92. A statement oft repeated by the Supreme Court. United States v. Catto, 384 U.S. 102, 114 (1966); Commissioner v. Hansen, 360 U.S. 446, 467 (1959); Automobile Club of Michigan v. Commissioner, 353 U.S. 180, 189-90 (1957); Brown v. Helvering, 291 U.S. 193, 204-05 (1934); Lucas v. American Code Co., 280 U.S. 445, 449 (1930). 
for all taxpayers," ${ }^{93}$ it follows that either the Commissioner's or the taxpayer's choice of method must be given presumptive effect. ${ }^{94}$ Given the relative self-interest of Commissioner and taxpayer, and the numerous extra-judicial considerations ${ }^{95}$ that go into "the equitable collection of revenue," ${ }^{96}$ Commissioner discretion is preferable to taxpayer discretion. ${ }^{97}$

\section{B. Nature and Limits of Section 446(b) Discretion}

Simply to call the section $446(\mathrm{~b})$ determination a matter of Commissioner discretion is meaningless without some notion of the standard of judicial review that will be applied to exercises of that discretion.

Given that some discretion has been granted, judicial review of a Commissioner determination is limited to an abuse of discretion standard of review consisting of two inquiries. ${ }^{98}$ First, as a threshold matter, a court must decide whether the determination was within the grant of discretion; that is, whether the action taken was both appropriate for agency discretion and within the range of discretionary actions granted..$^{99}$ If not, the determination does not

93. Treas. Reg. § 1.446-1(a)(2) (1957).

94. Compare Van Pickerill \& Sons, Inc. v. United States, 445 F.2d 918, 921 (7th Cir. 1971), where the Seventh Circuit, while using language to the effect that courts should not weigh the relative merits of accounting methods, sided with taxpayer's choice of alternative accounting methods. See also Peninsula Steel Prods. \& Equip. Co. v. Commissioner, 78 T.C. 1029, 1044-45 (1982). On the acceptability of taxpayer choice of accounting method, cf. Thor, 439 U.S. at 544 (taxpayer discretion would allow taxpayer to determine tax it wished to pay).

95. Cf. Natural Resources Defense Council, Inc. v. SEC, 606 F.2d 1031, 1046 (D.C. Cir. 1979) (weighing competing regulatory policies argues for nonreviewable discretion); Local 2855 , Am. Fed'n of Gov't Employees v. United States, 602 F.2d 574, 579 (3d Cir. 1979) (broad discretion suggests that nonjudicial factors go into decision); $K$. Davis, supra note 44, at 548-49.

96. Thor, 439 U.S. at 542. The statutory IRS purpose of "protect[ing] the public fisc," id., there enunciated can be seen to involve considerations that go beyond judicial interpretation of the "clearly reflects income" language.

97. "Clearly reflect income" determinations are explicitly considered appropriate for the Commissioner by the statute in contexts other than the evaluation of taxpayer's choice of method; section 446(b) explicitly gives the Commissioner discretion to choose an accounting method where the taxpayer had none, and $\$ 471$ explicitly gives the Commissioner discretion to choose inventory accounting methods which "most clearly reflect income." I.R.C. $\$ 471$ (1976). Of course, this argument might cut both ways; it might be said that the Congress knew how to grant discretion when it meant to.

98. It should be noted that, while the exercise of discretion is subject to a relaxed standard of review, the initial determination as to whether discretion exists is a matter over which the court has full scope of review.

99. Citizens to Preserve Overton Park, Inc. v. Volpe, 401 U.S. 402, 415-16 (1971); L. Jaffe, supra note 46, at 359; Berger, Administrative Arbitrariness: A Synthesis, 78 Yale L.J. 965, 973 (1969). Overton Park interpreted $\S 10(\mathrm{e})$ of the Administrative Procedure Act (APA), 5 U.S.C. $\S$ 706 (1976), which provides for review of agency action for arbitrariness. Id. $\S 706(2)(\mathrm{A})$. Though no cases specifically apply the APA to $\S 446$ (b) determinations, by its terms the APA would encompass tax litigation. Section 10(a) of the APA, 5 U.S.C. $\$ 701$ (a) (1976) provides that "[t]his chapter applies, according to the provisions thereof, except to the extent that-(1) statutes preclude judicial review; or (2) agency action is committed to agency discretion by law," while $\S$ 10(b) of the APA, 5 U.S.C. $\S 703(1976)$, provides that "[t]he form of proceeding for judicial review is the special statutory review proceeding relevant to the subject matter in a court specified by statute." Thus, the procedures for judicial review outlined in I.R.C. $\$ 6213$ (1976) (petition to Tax Court to redetermine assessment) and I.R.C. $\$ 7422$ (1976) (action for refund of taxes paid) is 
enjoy the relaxed standard of review. The second inquiry is one of whether or not discretion has been abused. The scope of this inquiry is somewhat flexible. ${ }^{100}$ In practice, courts reviewing "discretionary" applications of law to fact for abuse either apply a "rational basis" test or substitute their own judgment for that of the agency. ${ }^{101}$ The latter approach is highly questionable. ${ }^{102}$

The "rational basis" test of administrative discretion has two prongs. First, a court must decide what factors are legally relevant within the grant of discretion. ${ }^{103}$ Second, a court must inquire whether the determination was reasonably based on these factors. ${ }^{104}$

Decisions under section $446(\mathrm{~b})$ since Thor reflect a confusion about whether to apply a rational basis test or to substitute the judgment of the court for that of the Commissioner. In RCA Corp. $v$. United States, ${ }^{105}$ for instance, the Second Circuit declined to find an abuse of discretion, saying:

the "statutory review proceeding" referred to by the APA. See Pierson v. United States, 428 F. Supp. 384 (D. Del. 1977), where the district court considered the applicability of the APA to a discretionary decision under I.R.C. $\$ 7805$ (b) (1976) to make a ruling retroactive: "On its face, the APA would arguably appear to apply. . . . Nevertheless ... the Court and the parties have been unable to find any decision holding that the APA does regulate the scope of review . ..." 428 F. Supp. at 389 (footnote omitted). Query whether I.R.C. \& 6214(a) (1976), authorizing the Tax Court to "redetermine the correct amount," implies a stricter standard of review in Tax Court proceedings. It seems unlikely, however, that Congress intended Commissioner discretion to have greater weight in district courts than in tax courts. Cf. Bernuth v. Commissioner, 470 F.2d 710, 714 (2d Cir. 1972) ("black letter law" that Commissioner determinations in general enjoy presumption of correctness in Tax Court proceedings).

100. It has been suggested that once a matter is "committed by law" to agency discretion, it is immune from judicial review. Citizens to Preserve Overton Park, Inc. v. Volpe, 401 U.S. 402, 410 (1971); K. Davis, supra note 44, $\$ 28.05$, at 515. Under Professor Davis's approach, a determination that a matter was "committed to agency discretion by law" would be equivalent to a determination that it was not judicially reviewable. However, some agency actions not found to be "committed by law" to agency discretion would be reviewable on an "abuse of discretion standard." See APA § 10(a),(e), 5 U.S.C. $\S \S 701,706$ (1976). Such immunity from review is said to exist only where the statute provides "no law to apply." Overton Park, 401 U.S. at 410 (quoting S. Rep. No. 752, 79th Cong., 1st Sess. 26 (1945)). Thus the distinction is primarily semantic. Actions "committed to agency discretion" are unreviewable but some actions not so committed are reviewable under an "abuse of discretion" standard. Section 446(b) does not present such a case of unreviewable discretion.

101. Compare Gray v. Powell, 314 U.S. 402 (1941), where the Court stated that a lack of "dispute as to the evidentiary facts . . . does not permit a court to substitute its judgment for that of the Director," id. at 412, and that the reversal of the agency determination would not be had unless the factors considered by the agency are "so unrelated to the tasks entrusted by Congress to the Commission as in effect to deny a sensible exercise of judgment," id. at 413 , with Davis Warehouse Co. v. Bowles, 321 U.S. 144 (1944), where the Court substituted its own definition for an administrative determination. See generally $\mathrm{K}$. Davis, supra note 44, § 30.04-.07. Compare APA $\S 10(e), 5$ U.S.C. $\S 706(2)$ (A) (1976), which provides for review of administrative action for being "arbitrary, capricious, an abuse of discretion, or otherwise not in accordance with law."

102. The Supreme Court rejected substitution of judgment in Citizens to Preserve Overton Park, Inc. v. Volpe, 401 U.S. 402, 416 (1971): "The court is not empowered to substitute its judgment for that of the agency."

103. Id.; L. Jaffe, supra note 46 , at 181 . But see discussion of agency power to define relevant factors, infra note 118.

104. Citizens to Preserve Overton Park Inc. v. Volpe, 401 U.S. 402, 416 (1971); L. Jaffe, supra note 46 , at $586-87$.

105. 664 F.2d 881 (2d Cir. 1981), cert. denied, 102 S. Ct. 2958 (1982). 
The task of a reviewing court, therefore, is not to determine whether in its own opinion RCA's method of accounting for prepaid service contract income "clearly reflect[ed] income," but to determine whether there is an adequate basis in law for the Commissioner's conclusion that it did not. ${ }^{108}$

On the other hand, the Tax Court, in Peninsula Steel Products \& Equipment Co. v. Commissioner, ${ }^{107}$ while acknowledging the Commissioner's "broad discretion in determining whether an accounting method clearly reflects income," 108 reversed such a determination, stating, "We believe that the method used by [the taxpayers] clearly reflected their . . . income . . . and, accordingly, [the Commissioner] is without authority to change it." 100 The Tax Court approach, by substituting its own judgment for that of the Commissioner, seems to leave little room for the Commissioner to exercise his "discretion." The Second Circuit's "adequate basis in law" test in $R C A$ seems to approximate the more limited review of the "rational basis" test.

This rational or reasonable basis test is the better rule in a case where the matter has been found appropriate for agency discretion. To say that an agency has discretion in a matter but that an exercise of such discretion is subject to the substitution of a court's opinion is self-contradictory. ${ }^{110}$ If a grant of discretion is to have meaning, it must impose some limit on the scope of judicial review.

Commissioner discretion under section $446(b)$ is not thus made limitless. A taxpayer may show an abuse of discretion under the rational basis test, by showing that the motivating factor for the determination is irrelevant ${ }^{111}$ or nonexistent, ${ }^{112}$ or that a relevant factor was grossly exaggerated in the decision, ${ }^{113}$ or that the determination is inconsistent with prior determinations. ${ }^{114}$

106. Id. at 886 (brackets in the original).

107. 78 T.C. 1029 (1982).

108. Id. at 1044.

109. Id. at 1052 (footnote omitted).

110. Cf. K. Davis, supra note $44, \S 30.05$ (substitution of judgment not associated with limited scope of review).

111. Cf. Wong Wing Hang v. INS, 360 F.2d 715, 719 (2d. Cir. 1966) (use of an impermissible basis of decision is abuse of discretion); Koebig \& Koebig, Inc. v. Commissioner, 1964 T.C.M. (P-H) 9 64,032, at 64,200 (1964) ("unable to find a sound reason for [Commissioner's] contentions" and Commissioner "not empowered to reconstruct ... income . . . to secure more favorable tax results"; thus greater revenue by itself apparently is an irrelevant consideration).

112. Cf. IBM Corp. v. United States, 343 F.2d 914, 920 (Ct. Cl. 1965) (discretion to make ruling prospective only, under I.R.C. $\$ 7805$; " " $[t]$ he Commissioner cannot tax one and not tax another without some rational basis for the difference,' " quoting United States v. Kaiser, 363 U.S. 299, 308 (1960) (Frankfurter, J., concurring)).

113. L. Jaffe, supra note 46, at 586-87. In Farmers' and Merchants' Bank v. United States, 476 F.2d 406 (4th Cir. 1973), the Fourth Circuit found no rational basis for an exercise of discretion under I.R.C. $\$ 7805$ (1976) to make a favorable ruling effective for prior years for which returns were filed consistent with the ruling, but not allowing amended returns to take advantage of the ruling. While the court did not consider this point, the prospective effect might have been based on administrative convenience-to avoid the burden of processing amended returns. Such a basis might have been seen as insufficient, of itself, to support the action.

114. Bay State Gas Co. v. Commissioner, 689 F.2d 1 (1st Cir. 1982). Bay State concerned the Commissioner's determination to require a utility to accrue as income gas delivered after the last 
The Commissioner's discretion is also limited by specific statutory ${ }^{115}$ or regulatory ${ }^{116}$ authorizations of the accounting method challenged. A proper application of the rational basis test would not, however, allow a taxpayer to prevail merely by proving that his income was "clearly reflected."

Nevertheless, implicit in judicial review of any discretionary administrative determination is some judicial inquiry into the content of the language and the legislative purpose of the statute considered. At the very least, the reviewing court must decide that the determination is not contrary to the "clear purpose" of the statute. ${ }^{117}$ In the section 446 context, a court is likely to define the legally relevant factors that the Commissioner must consider in exercising discretion. ${ }^{118}$ To do so, the reviewing court must first impart some meaning to the "clearly reflect income" language. The court may then develop the legally relevant discretionary factors by considering the statutory language in the context of the purpose of the Internal Revenue Code, under

meter reading for the year for one group of consumers, but not for another. The court found an abuse of discretion, but apparently did not challenge the Commissioner's power to require such accruals for all customers.

115. Cf. Peninsula Steel Prods. \& Equip. Co. v. Commissioner, 78 T.C. 1029, 1057-1059 (1982) ( $\$ 472$ authorization of LIFO inventories limits Commissioner discretion to disallow use of LIFO). As a matter of statutory construction a particular authorization of a deduction would supplant the general grant of discretion to determine whether income is clearly reflected in $\S$ 446(b). Consider the example of the Accelerated Cost Recovery System, I.R.C. § 168 (Supp. VI 1982); the fast capital write-offs there allowed would not be in accordance even with the conservative principles of GAAP, but the Commissioner presumably cannot deny such deductions as not "clearly reflecting income." Cf. generally APA § 10(e), 5 U.S.C. § 706(2)(C) (1976) (determination reversible if "in excess of statutory . . . limitations").

116. Frysinger v. Commissioner, 645 F.2d 523, 527 (5th Cir. 1981). But cf. 10 Mertens Law of Federal Income Taxation $\S 60.16$ (1976 rev.) (Commissioner not bound by erroneous regulations).

117. L. Jaffe, supra note 46 , at 569-75; K. Davis, supra note $44, \S 30.04$, at 550 .

118. There remains some question as to who should determine the relevant factors. In Citizens to Preserve Overton Park v. Volpe, 401 U.S. 402 (1971), the Supreme Court made its own inquiry into whether the agency determination was based on "relevant factors," id. at 416, and the Court itself considered the proper weighting of factors according to statutory purpose, id. at 411-12. Nevertheless, where agency lawmaking discretion has been granted, a court might properly limit the scope of review of an agency definition of legally relevant factors to a consideration of whether such factors could rationally be found legally relevant. Wong Wing Hang v. INS, 360 F.2d 715, 719 (2d Cir. 1966) (discretion abused if decision "rested on . . . 'considerations that Congress could not have intended to make relevant.' " (quoting United States ex rel. Kaloudis v. Shaughnessy, 180 F.2d 489, 491 (2d Cir. 1950)). See generally L. Jaffe, supra note 46, at 569-75 (if reasonable men may differ as to purpose of statute, reasonable agency interpretation stands). The limited review of agency lawmaking depends on the scope of discretion granted. See generally Monaghan, supra note 48, at 25-31 (function of judicial review is to determine whether agency lawmaking is within boundaries set by Congress). While the language and history of $\S 446(\mathrm{~b})$ are ambiguous as to whether the Commissioner has discretion to define the "clearly reflect income" test, or merely to apply it, supra text accompanying notes 53-61, cases decided under $\$ 446$ (b) tend to inquire into the meaning and legislative purpose of the "clearly reflect income" language. See discussion of Automobile Club of Michigan, 353 U.S. 180 (1957); American Automobile Ass'n v. United States, 309 U.S. 687 (1961); Thor Power Tool Co. v. Commissioner, 439 U.S. 522 (1979), infra text accompanying notes 133-48. Thus, the same cases which find the grant of discretion under $\S 446(\mathrm{~b})$ leave authority in the courts to define the statutory language and determine the legally relevant factors. Of course, if a court were to find that a Commissioner definition of the legally relevant factors was reversible only if such factors could not have been based on the statute, Commissioner challenges to accounting methods could be made much more 
which the discretion arises. ${ }^{119}$ Thus, to define the law within which a Commissioner determination must have an "adequate basis," we turn to both the development of judicial doctrine and a statutory interpretation of the "clearly reflect income" language.

\section{EMerging Content of "Clearly Reflect Income” Discretion IN THE ACCRUAL ACCOUNTING CONTEXT}

An inquiry into the emerging content of the "clearly reflect income" test reveals a shift from the early definition of tax accounting "income," which identified it with financial accounting income, to a definition of tax accounting income that explicitly recognizes the incompatibility of financial accounting income with tax accounting goals. This new definition recognizes as a significant factor of tax accounting the "responsibility of the Internal Revenue Service ... to protect the public fisc." ${ }^{120}$ Implicit in this doctrine is recognition of considerations of tax equity in the discretionary application of the "clearly reflect income" test. Under such an approach, the defeat of horizontal equity through the manipulation of an accounting method may be the Commissioner's "rational basis" for disallowing such an accounting method.

\section{A. Rejecting "Income" According to GAAP}

1. Judicial Doctrine from Anderson to Thor. Judicial parsing of the "clearly reflect income" language originally focused on the "clearly reflect" portion of the test. In early decisions, the concept of "income" was assumed to be equivalent to the financial accounting definition of income.

The seminal accrual accounting case, United States $v$. Anderson, ${ }^{121}$ is the basis for this notion of financial and tax accounting "income" equivalency. In Anderson, the Court interpreted section 13(d) of the 1916 Act. ${ }^{122}$ This section for the first time specifically authorized accrual accounting for tax purposes by providing that tax accounting be according to the taxpayer's book method. In applying accrual tax accounting concepts to the timing of a deduction for munitions taxes not payable until the year after the activity, and of income that gave rise to the tax, the Court required "scientific accounting principles ... . [of] charging against income earned during the taxable period ... the expenses incurred in and properly attributable to the process of earning income during that period." 123 The Court thus stated the "matching

easily. This Note will assume the less deferential standard of review in which the court defines which factors are legally relevant.

119. L. Jaffe, supra note 46 , at $181,570-73$.

120. Thor Power Tool Co. v. Commissioner, 439 U.S. 522, 542 (1979).

121. 269 U.S. 422 (1926).

122. Revenue Act of 1916 , ch. $463, \S 13$ (d), 39 Stat. 756, 771 (repealed 1918). This section is a predecessor of the current $\S 446(\mathrm{~b})$. See supra note 56.

123. 269 U.S. at 440. 
principle" of accrual accounting, a concept of income that is consonant with financial accounting goals. ${ }^{124}$

Thus the definition of income seemed settled as the matching of expenses with revenues generated from the period's activities. Such a conception of income had great staying power, but was destined to prove unworkable for tax accounting purposes. Litigation in the circuits following Anderson illustrates the problems with a "matching" concept of tax income. With the construction of the "income" language settled, such litigation tended to focus on the "clearly reflect" portion of the test. When confronted with the tension between a Revenue Act that seemed to authorize cash-receipts-and-disbursements accounting and the fact that the cash method rarely, if ever, properly matches income and expenses, the Ninth Circuit parsed its way out of the problem with the "clearly reflect" language in Osterloh v. Lucas. ${ }^{125}$ It decided that no "literal construction [of 'clearly reflect'] was contemplated . . . . [A]ll that is meant is that the books shall be kept fairly and honestly . . ." ${ }_{126}$ The Sixth Circuit, in Huntington Securities Corp. v. Busey, ${ }^{127}$ further minced the "clearly reflect" language: "'Clearly,' as used in the statute, means plainly, honestly, straightforwardly and frankly, but does not mean 'accurately' ..."128 . But the Second Circuit, struck by a sense that congress could not have intended that good faith but wholly inaccurate accounting methods pass for tax purposes, decided in Caldwell $\cdot v$. Commissioner" to "read 'clearly reflect the income' . . . to mean rather [than good faith,] that income should be reflected with as much accuracy as standard methods of accounting practice permit." $" 30$

This last excerpt reflects an adherence to a "standard methods" of financial accounting concept of income, comprehending the matching principle. The staying power of the Anderson decision helped cause the difficulty in construing the "clearly reflect" language of the test. Yet even while the circuits were struggling to reconcile the "clearly reflect" language with a matching concept of income, the Supreme Court was backing off from a strict

124. The government, the prevailing party, cited in its brief two financial accounting texts and one tax accounting text. Id. at 425 . For a current statement of the matching principle as a "pervasive principle" of GAAP, see American Institute of Certified Public Accountants, APB Statement No. 499 154-161 (October, 1970), reprinted in Financial Accounting Standards Board, Financial Accounting Standards: Original Pronouncements as of July 1, 1976 at 466-67 (1976) [hereinafter cited as APB Statement No. 4]. Cf. H. Finney and R. Oldberg, Lawyer's Guide to Accounting 79-80, 90, 94-95 (1955) (matching principle fundamental to financial accounting).

The decision in favor of financial accounting in Anderson went against the taxpayer, who sought a later accrual of the munitions tax to offset the higher income tax rates. Cf. Miller \& Vidor Lumber Co. v. Commissioner, 39 F.2d 890, 892 (5th Cir. 1930), where the Fifth Circuit also applied financial accounting matching to reject a taxpayer's attempt to defer an expense to a more highly taxed year.

125. 37 F.2d 277 (9th Cir. 1930).

126. Id. at 278 .

127. 112 F.2d 368 (6th Cir. 1940).

128. Id. at 370 .

129. 202 F.2d 112 (2d Cir. 1953).

130. Id. at 115 . 
matching principle. In North American Oil Consolidated v. Burnet, ${ }^{131}$ the Court held that the time the right to receive revenues matures determines the taxable year of inclusion rather than the year the expenditures and activities producing the revenues occurred, hinting that ability to pay was more important than matching in tax "income." 132

A more explicit rejection of the financial accounting "matching" conception of income was not to come until the Supreme Court decided American Automobile Association v. United States $(A A A)^{133}$ in 1961. Prior to $A A A$, several circuits had upheld the use of accounting methods that deferred tax recognition of income already received in cash until the year in which the properly matched expenses were to be incurred. ${ }^{134}$ Four years prior to $A A A$, in Automobile Club of Michigan v. Commissioner (Michigan), ${ }^{135}$ the Court had rejected such an accounting method on the ground that the "pro rata allocation of the membership dues ... is purely artificial and bears no relation to the services" that produce the income. ${ }^{138}$ But it is not clear from the holding in Michigan whether the Court was rejecting the financial accounting matching principle or rejecting the taxpayer's factual basis for matching revenues with expenses. ${ }^{137}$

$A A A$ involved the same accounting practice that the Court rejected in Michigan. That the identical issue required Supreme Court consideration four years later demonstrates the ambiguity in the Michigan holding. The taxpayer's attempt to distinguish Michigan highlights the confusion about whether the "clearly reflect income" test turned on "clearly reflect" or on "income." The $A A A$ taxpayer sought to distinguish Michigan on the ground that $A A A$ 's accounting method was more "clear"-that is, the method in fact accorded with the financial accounting concept of revenues-matched-with-expenses income based on statistical experience. ${ }^{138}$ The $A A A$ taxpayer saw no need to show that the income clearly reflected by financial accounting systems was the

131. 286 U.S. 417 (1932).

132. Other Supreme Court decisions indicating that activity matching was not the only principle of tax "income" include Guaranty Trust Co. v. Commissioner, 303 U.S. 493 (1938) (recognition upon receipt or accrual, regardless of timing of associated activities); Continental Tie \& Lumber Co. v. United States, 286 U.S. 290 (1932) (income recognized at genesis of right to receive). Cf. Heiner v. Mellon, 304 U.S. 271 (1938) (matching revenues and expenses of entire protracted transaction does not affect taxation of results of particular period); Burnet $v$. Sanford \& Brooks Co., 282 U.S. 359 (1931) (same).

133. 367 U.S. 687 (1961).

134. Bressner Radio, Inc. v. Commissioner, 267 F.2d 520 (2d Cir. 1959) (television service contracts) (citing Anderson); Schuessler v. Commissioner, 230 F.2d 722 (5th Cir. 1956) (furnace service contracts); Beacon Publishing Co. v. Commissioner, 218 F.2d 697 (10th Cir. 1955) (prepaid newspaper subscriptions, recognition of income deferred until year of delivery).

135. 353 U.S. 180 (1957).

136. Id. at 189.

137. The Court distinguished Beacon and Schuessler, while expressing no opinion on their merits, on the ground that the certainty that services would later be performed was greater in those cases. Id. at 189 n.20. This distinction reinforces the ambiguity of the holding, since, if valid, the taxpayer need only show the greater certainty of the associated expenses-i.e., more proper matching.

138. 367 U.S. at 691 . Note the taxpayer reliance on accounting testimony. 
same "income" intended to be clearly reflected for tax purposes. The Court found these clear-reflection arguments irrelevant, a finding that must be read as a redefinition of the "income" concept. ${ }^{139}$ The Court expressly repudiated the notion that financial accounting "income" was controlling for tax purposes. ${ }^{140}$ While the holding was not explicit in its rejection of the matching principle, ${ }^{141}$ clearly the matching principle as applied by financial accounting was rejected along with the idea that tax "income" was the same as financial income. Two years later, in Schlude $v$. Commissioner, ${ }^{142}$ the Court again considered a prepaid income deferral accounting method that was claimed to have sufficient factual basis to invoke the matching principle, and again rejected it. ${ }^{143}$

The recognition that the financial accounting concept of income did not control the construction of section 446(b) "income" for tax purposes, implicit in the $A A A$ decision, was made explicit in Thor Power Tool:

[T] he presumption petitioner postulates [that GAAP clearly reflects income] is insupportable in light of the vastly different objectives that financial and tax accounting have. The primary goal of financial accounting is to provide useful information to management, shareholders, creditors, and others properly interested; the major responsibility of the accountant is to protect these parties from being misled. The primary goal of the income tax system, in contrast, is the equitable collection of revenue; the major responsibility of the Internal Revenue Service is to protect the public fisc . . . . In view of the Treasury's markedly different goals and responsibilities, understatement of income is not destined to be its guiding light. ${ }^{144}$

139. Id. at 692 . The Court does invoke the "clearly reflect" language by referring to the "clarity of an accounting system," id., but the rejection of financial accounting matching principles is best read as a redefinition of "income." By exalting the certainty requirement over the matching principle, $A A A$ 's tax accounting requirement is at odds with the financial accounting approach to income and the matching concept.

As an alternative holding, the Court found that the deferrals sought were barred by congressional intent in repealing $\S \S 452$ and 462 of the 1954 Code, which would have expressly allowed such deferrals. The Court seemed particularly influenced by the magnitude of the loss to the Treasury which would be caused by such a rule. Id. at 694-97.

140. Id. at 692-93.

141. Whether some less rigorous tax matching principle remains is ambiguous, since the Court again distinguishes Beacon and Schuessler "on the same grounds which made them distinguishable in [Michigan]." Id. at 691 n.4. (citation omitted).

142. 372 U.S. 128 (1963).

143. In Schlude, a franchise dance instructor deferred recognition of income for lessons contracted for and prepaid until the lessons were actually requested. The Court again rejected the putative matching expenses as too uncertain, since the lessons might be forfeited if not demanded. Id. at 135. While the holding implies that the matching has some relevance for tax purposes, it is not the same matching principle that applies for financial purposes, which demands less certainty.

The tenacity of the GAAP matching principle in income tax accounting, even after the $A A A$ and Schlude decisions, is demonstrated by Boise Cascade Corp. v. United States, 530 F.2d 1367 (Ct. Cl.), cert. denied, 429 U.S. 867 (1976), where the Court of Claims rejected the Commissioner's disallowance of the taxpayer's GAAP based income deferral accounting method.

A further withdrawal from financial accounting principles is evidenced in Frank Lyon Co. v. United States, 435 U.S. 561 (1978), where the Court found that the financial accounting characterization of a transaction did not control for tax purposes. Id. at 577 .

144. 439 U.S. 523, 542 (1979). 
The implication of the passage goes further than a rejection of the taxpayer's accounting method; it is a statement that the financial accounting concept of income, based on entirely different goals, has little to do with the tax statute concept of income.

2. Income After Thor: An Index of Taxpaying Ability. The Michigan-toThor line of cases appears more consistent when read as defining the tax concept of income rather than as passing on the technical accuracy of an accounting method in reflecting an assumed financial accounting concept of income. By focusing on the "clearly reflect" question and avoiding the "What is income?" question, the taxpayer litigants in $A A A$ and Schlude were barking up the wrong tree. But these cases do more than simply reject financial accounting income; they articulate an affirmative notion of what tax accounting income is.

This notion of tax "income," pursuing the goal of the "equitable collection of the revenue," comprehends the consideration of horizontal and vertical equity. The inclusion of horizontal equity as a tax income consideration is evidenced by the Court's concern in Thor that financial accounting principles, which allow many choices in treatment, would give the taxpayer too much latitude to choose his tax:

Variances of this sort . . . are questionable in a tax system designed to ensure as far as possible that similarly situated taxpayers pay the same tax. If management's election among "acceptable" options were dispositive for tax purposes, a firm, indeed, could decide unilaterally-within limits dictated only by its accountants-the tax it wished to pay. Such unilateral decisions would . . . make the Code inequitable ....145

That this tax "income" doctrine also considers vertical equity relevant is evidenced by the Court's holdings severely limiting deferrals of income received in Michigan, $A A A$, and Schlude. A taxpayer who has received cash in the current year has more ability to pay tax than one who has not, even though the cash received is associated with a promise to perform future services. Though it would be misleading to investors to recognize income currently that will not be earned until a later year, horizontal and vertical equity require a taxpayer with cash in pocket to share that cash with the government currently. ${ }^{146}$ This concern for taxation based on current ability to pay is reflected

145. Id. at 544. An economic efficiency analysis of the Thor case is intriguing, since the transaction giving rise to the deduction was a paper book entry. However, this book entry, seemingly encouraged by the tax law, would affect Thor's financial statements and thus might affect transactions with the owners. The tax benefit sought might also influence the size of the planned overrun of spare parts, since the manufacturer expected the tax law to subsidize part of the cost of the overrun. By disallowing the write-down, the Court removed the uneconomic incentive.

146. Perfect equity, however, might allow such a taxpayer to reduce his taxable income by the estimated future expenses associated with this income. Otherwise, a taxpayer who receives $\$ 100$ in income this year subject to no promise is treated the same as a taxpayer receiving $\$ 100$ subject to a promise to perform expensive services next year, though their taxpaying abilities differ. Such accruals normally fail the "all events" test for current deductions, and are not 
in the $A A A$ Court's requirement of a stronger showing that expenses are properly matched for tax purposes than for financial purposes where "an accounting system ... defers receipt" (receipt meaning recognition) ${ }^{147}$ of cash that is in the possession of the taxpayer. ${ }^{148}$

Thus the divergence between tax "income" and financial income may be defined: financial income is intended to be a comparative measure of a year's results, allowing an outsider, with the benefit of elaborate disclosure of accounting practices, to compare the results of different periods or different organizations. ${ }^{148}$ Tax "income," on the other hand, is intended to be an index of a taxpayer's current ability to pay tax. Disclosure of accounting practices will protect users of financial statements, but such disclosure cannot protect the tax system, which takes income as an absolute. Transactions such as advance receipt of income and deferral of expenses, while not affecting the comparative measure of period performance, do affect the index of ability to pay taxes implicit in tax "income." An explicit application of this ability-topay concept may be seen in RCA Corp. $v$. United States ${ }^{150}$ where the Second Circuit rejected an income deferral accounting method on the principle that "[t]ax accounting ... tends to compute taxable income on the basis of the taxpayer's present ability to pay the tax, as manifested by his current cash flow." 151 The case law thus relates tax "income" to ability to pay.

\section{B. Legislative History and Tax Equity}

The concept of tax "income" as an index of ability to pay tax ${ }^{152}$ has support in the legislative history of the income tax. The original income tax, passed in 1913, and the sixteenth amendment, which authorized it, were a response to the perceived unfairness of the then current system of raising revenues through tariffs on goods. The poor and the working class were seen to be shouldering a disproportionate burden of the tariff on consumption goods; the income tax was intended to shift a fair share of the burden to the wealthy. ${ }^{153}$ Implicit in this purpose is the notion of vertical equity, that those with a greater ability to pay should pay a greater tax. According to the House

allowed. E.g., Spencer, White \& Prentis, Inc. v. Commissioner, 144 F.2d 45 (2d Cir.), cert. denied, 323 U.S. 780 (1944). However, deductions for a reserve to cover these expenses may be allowable. See 4 Federal Taxes $(\mathrm{P}-\mathrm{H})$ \ 20,577 (1982) and cases cited therein.

147. 367 U.S. at 692.

148. Accord Mooney Aircraft, Inc. v. United States, 420 F.2d 400, 408 (5th Cir. 1969)

("Schlude and $A A A$, however, have significance far beyond their particular facts" and call into question all deferrals and accruals.).

149. APB Statement No. 4, supra note 124, at $9993,95-106$.

150. 664 F.2d 881 (2d Cir. 1981), cert. denied, 102 S. Ct. 2958 (1982).

151. Id. at 888 .

152. "Income" might more precisely be called an index of increase in ability to pay tax, since an index based on either wealth or consumption may also be said to reflect taxpaying ability. See R. Musgrave \& P. Musgrave, supra note 6, at 242-90.

153. See H.R. Rep. No. 416, 62d Cong., 2d Sess. 2 (1912); H.R. Rep. No. 5, 63d Cong., 1st Sess. xxxvi-ix (1913). 
Report on the 1913 Act, "The tax upon incomes is levied according to the ability to pay ...."154

If a tax upon incomes is a tax upon ability to pay, tax "income" must be an index of ability to pay. The language of the 1913 Act supports such a reading. "Income" in its first appearance is used in the context of the computation of the tax: "That there shall be levied, assessed, collected and paid annually upon the entire net income . . . a tax of one per centum per annum upon such income." 155 The current Code continues this conception of "income"; ultimately "taxable income" is the index upon which the tax is based. ${ }^{156}$

This tax equity is part of the "clear purpose" of the tax law. ${ }^{157}$ Thus the Commissioner ought to be able to consider the taxpayer's relative ability to pay tax when making a clearly-reflects-income determination. Even if the Commissioner's discretion is limited to passing on the technical accuracy of the accounting method in its application, vertical equity, and hence taxpaying ability, is a relevant consideration in determining whether "income" is clearly reflected. When reviewing the Commissioner's determination that an accounting method does not "clearly reflect income," courts should treat the "income" language as an index of taxpaying ability, to be determined without reference to financial accounting rules, which are designed for comparative purposes. An accounting method is thus acceptable only insofar as it reflects current ability to pay tax without regard to an attempt to match current with future expenses that do not affect current taxpaying ability.

Such an "income" standard allocates the roles of reviewing court and agency according to their expertise. Thus read, the Michigan-AAA-SchludeThor line of cases interprets the legal construction of the section 446(b) "income" language. The Commissioner's role under section $446(\mathrm{~b})$ is to determine whether the accounting system used, as applied, reflects this tax definition of income; and it is thus the Commissioner, and not the court, that weighs the relative merits of accounting systems. The courts simply set the legal goals of the accounting system. To disallow an accounting application, the Commissioner need only show the reason why the method tended not to reflect taxpaying ability. Or, to rephrase the same test, disallowance of an

154. H.R. Rep. No. 5, 63d Cong., 1st Sess. xxxvii (1913).

155. Revenue Act of 1913, Pub. L. No. 16, § IIA, subd. 1, 38 Stat. 114, 166 (repealed 1916). That "income" was meant as a measurement of taxpaying ability, rather than a taxable corpus, see Opinions of the Honourable John K. Shields, Hon. Cordell Hull, and Thurlow M. Gordon, Special Assistant to the Attorney General on the Proposed Income Tax Provisions of the Pending Tariff Bill, S. Doc. No. 171, 63d Cong., 1st Sess. 8-9 (1913) (statement of M. Gordon). Gordon's opinion was rendered in opposition to an amendment which would have barred retroactive effect of the Act. The amendment was not adopted.

156. I.R.C. $\S 1$ (1976). Of course, "income" as an index of taxpaying ability is (and always has been) modified by the tax subsidy provisions of the Code. See supra text accompanying note 9. Even the 1913 Act exempted from income interest on state issued bonds. Revenue Act of 1913, Pub. L. No. 16, § IIB, 38 Stat. 114, 167 (repealed 1916).

157. See supra text accompanying note 50 . 
accounting method that defeats tax equity accords with the "clear purpose" of the tax statute, and is thus proper as a matter of agency "legal" discretion. Thus, abuse itself becomes a ground for disallowing an accounting method. ${ }^{158}$

The next step is to apply this analysis where the accounting practice challenged undeniably satisfies the technical rules of a tax accounting method, a situation indistinguishable in principle from the Michigan-AAA-SchludeThor line of cases. ${ }^{159}$

\section{Commissioner Discretion and a TaXPaying Ability Concept of "INCOME" APPLIED to ACCRUAL ABUSE}

\section{A. "Abuse" Standard and Tax Equity}

As demonstrated, an accounting method may be disallowed if it does not reflect "income," defined as ability to pay tax, thus comprehending tax equity. Such a disallowance is desirable since it is an effective weapon against taxpayer abuse through manipulation of accounting method. The definition of tax shelter abuse offered earlier ${ }^{160}$ demonstrates the consonance between tax equity and tax shelter abuse, abuse defined as the defeat of horizontal or vertical equity without participation in a tax favored activity.

Under the section $446(\mathrm{~b})$ analysis suggested, a tax shelter transaction defeating horizontal or vertical equity that depends on the application of a particular accounting method would be subject to disallowance as not reflecting ability to pay tax. Where the defeat of vertical equity results from participation in an activity qualifying for an intentional tax subsidy, the accounting method would not be subject to disallowance since the Commissioner's discretion is limited by specific provisions of the Code and regulations. ${ }^{161}$

\section{B. Disallowance of Accrual Accounting}

1. Application of Taxpaying Ability Analysis. The suggested taxpaying ability approach to section 446(b) discretion is consistent with the cases applying the "clearly reflect income" test to disallow cash accounting. The Burck court, for example, considered the capital gains income the taxpayer sought to offset with a substantial interest prepayment to be " 'real' income which should properly be reflected in taxpayer's tax liability." 162 Thus the "income" that was "materially distorted" by cash accounting in that case was viewed as the taxpayer's ability to pay tax, which included the capital gains income. The "materially distorts income" test was applied even though the rules of an authorized accounting method were strictly followed.

158. That is, abuse as the defeat of tax equity. See supra text accompanying notes 10-16.

159. As noted above, supra note 82 , Michigan, $A A A$, and Schlude may be read as cases dealing with the proper time for recognizing income under the accrual method, rather than as cases rejecting the accrual method itself in the particular application.

160. See supra text accompanying notes 133-44.

161. See supra text accompanying notes 115-16.

162. Burck v. Commissioner, 533 F.2d 768, 772 (2d Cir. 1976). 
Decisions dealing with cash accounting may on their face be weak precedent, though, for the disallowance of accrual accounting as not clearly reflective of income. Both courts ${ }^{163}$ and the $\operatorname{Code}^{164}$ have historically viewed the cash method as a sacrifice in accuracy for the sake of simplicity of tax accounting for relatively unsophisticated taxpayers. The tenacious GAAP conformity argument cuts against the cash method, since cash accounting is not ordinarily acceptable for financial purposes. ${ }^{165}$ Thus, when the recognized inaccuracies of the cash method are manipulated by relatively sophisticated taxpayers, ${ }^{186}$ courts may be more willing to throw out an otherwise permissible cash accounting method than an accrual method, or at least find a "reasonable basis" to do so. ${ }^{167}$

Yet this distinction is valid only insofar as the cash method is, in fact, inherently more subject to manipulation than the accrual method. As demonstrated, the accrual method is also subject to manipulation. Accordingly, the "material distortion of income"168 standard developed as a test of abuse under the cash method ought equally to apply to accrual accounting. This test accords with Commissioner discretion under a tax equity conception of section 446(b) "income."

When the test is applied to the specific abuses of accrual accounting considered earlier, the Commissioner's authority to disallow accrual accounting becomes apparent. In the situations of both the advance accrual of deferred rent at full value and the Rule of 78 s interest amortization, the difference between the present value of the payment due and the dollar amount of

163. United States v. Catto, 384 U.S. 102, 110-11, 116 (1966) ("sacrifice in accounting accuracy under the cash method represents an historic concession . . . to provide . . . for farmers and ranchers in need of a simplified accounting procedure'); Frysinger v. Commissioner, 645 F.2d 523, 527 (5th Cir. 1981) (citing Catto; cash method as "historic concession for farmers"). Cf. Osterloh v. Lucas, 37 F.2d 277, 278 (9th Cir. 1930) (recognition that cash method rarely reflects income).

164. Compare the 1916 Act committee report language:

As two systems of bookkeeping are in use in the United States, one based on the cash or receipt basis and the other on the accrual basis, it was deemed advisable to provide in the proposed measure that [a taxpayer] may make return[s] . . on either the cash or accrued basis ....

H.R. Rep. No. 922, 64th Cong., 1st Sess. 4 (1916), with the 1954 Code committee reports: In the case of a taxpayer whose sole income is wages, duplicate tax returns or other records may be sufficient to constitute the use of the method of accounting. . . . Thus, the great bulk of such taxpayers who file returns on the cash basis will be considered to be using that method and hence ordinarily not subject to having their income computed on a basis which the Secretary or his delegate determines will clearly reflect income.

House Report, supra note 55, at A157, reprinted in 1954 U.S. Code Cong. \& Ad. News 4017, 4296; Senate Report, supra note 55, at 299, reprinted in 1954 U.S. Code Cong. \& Ad. News 4621, 4939.

165. APB Statement No. 4, supra note 123, 925.

166. See Burck v. Commissioner, 533 F.2d. 768, 769 (2d Cir. 1976) ("This case arises out of the ever-present potential for arbitrariness and evasiveness which is inherent in the cash-basis method of income tax accounting.").

167. See supra text accompanying note 23, (citing Burck v. Commissioner, 533 F.2d 768, 773 (2d Cir. 1976)).

168. See Burck v. Commissioner, 533 F.2d 768, 773 (2d Cir. 1976); supra note 23 and cases cited therein. 
the current deduction taken demonstrates that "income" so computed does not reflect the taxpaying ability of those similarly situated. ${ }^{169}$ The defeat of horizontal equity is a sufficient "reasonable basis" for the disallowance of accrual accounting as not clearly reflecting income in this situation. The Commissioner could thus require cash accounting for this item. ${ }^{\mathbf{1 7 0}}$

The application of such a horizontal equity test is consistent with the result, if not the reasoning, of the Mooney case. While the Fifth Circuit there did not consider the diminished present value of the aircraft retirement "bonds" accrued, clearly a promise to pay $\$ 1,000$ approximately twenty years later did not reduce the manufacturer's current ability to pay tax as much as a current $\$ 1,000$ expense. The Mooney court was correct in finding the delay in payment of the obligation "too long," but its reliance on the diminished likelihood of payment was not the best ground for this finding.

2. Accrual Accounting Tax Subsidy. Determining that horizontal equity is defeated is but half the inquiry into whether tax equity is defeated and an accrual accounting method does not clearly reflect income. An accounting system may defeat horizontal equity but still be acceptable if the inequity is due to a specific tax subsidy provision of the Code, or possibly the regulations. But can the use of an accounting method itself be a favored activity, the object of an effective tax subsidy?

As surprising as this possibility sounds, such would seem to be the assertion of the Fifth Circuit in limiting the Commissioner's discretion to

169. A plan such as the sale-leaseback can also defeat economic efficiency. The buyer-lessor may be no more efficient a manager than the seller-lessee, and, if the seller-lessee is profitable, may also be no more able to take advantage of the intended tax benefits of property ownership such as accelerated depreciation and the Investment Tax Credit. However, with a cash method buyer-lessor, the value of the deferral to both parties may make such an uneconomic transaction post-tax advantageous to both parties. If such a transaction takes place, economic efficiency is defeated.

170. This may seem a harsh result, since even a limited matching principle and horizontal equity require that some account be taken of the absolute future obligation to pay money arising from the current year's income-producing activities. Considering the hypothetical suggested supra text accompanying notes 24-25, horizontal equity would require that $B$ at least be given the same deduction as $A$, that is, for the $\$ 6,000$ present value of his future rent payment, if we ignore $B$ 's increased liquidity. But cf. Mooney Aircraft, Inc. v. United States, 420 F.2d. 400 (5th Cir. 1969) (liquidity considered under $\S 446(\mathrm{~b})$ ). The Commissioner could simply require that the deduction be discounted; however, there might be administrative problems in determining the discount rate, and discounting goes more to recharacterizing a transaction than to disallowing an accounting method. Cf. I.R.C. $\S 483$ (1976) (allowing recharacterization of deferred payment sales for "imputed interest"). Here, an interesting interplay with avoidance intent is raised. While intent to avoid taxes may be irrelevant to whether income is clearly reflected, see supra text accompanying notes 14-16, when a taxpayer purposely structures a transaction so that neither cash nor accrual accounting will accurately reflect taxpaying ability, he ought to accept the risk that the Commissioner will require the accounting method which is more favorable to the government. But $\mathrm{cf}$. Loftin \& Woodard, Inc. v. United States, 577 F.2d 1206, 1229 (5th Cir. 1978) ("[I]t would seem that such a showing [of Commissioner abuse of discretion] could be predicated upon a decision to use an accounting method that is inaccurate under the circumstances."). Where there are nontax motives for the deferral, the lessee can avoid trouble by characterizing the discounted value as 
disallow the cash accounting method to a tax-shelter farmer, in Frysinger $v$. Commissioner. ${ }^{171}$ The Frysinger court, while acknowledging a "distortion created by the deduction" for prepaid feed expenses, ${ }^{172}$ found that the distortion was intended by regulations governing "special privileges . . . with regard to tax accounting for farm expenditures." 173 This holding may be seen as a tax subsidy for farming, but it is better read as a tax subsidy for simplified accounting methods for particular classes of taxpayers. ${ }^{174}$

The possibility that in certain situations the inaccuracies of an accounting method will be tolerated as a tax subsidy for simplified accounting leads to an inquiry into whether accrual accounting could be thus favored in the tax avoidance situation being considered. Some intention to favor book accounting methods, including accrual accounting methods, must be inferred from the section 446(a) direction that "[t]axable income shall be computed under the method of accounting on the basis of which the taxpayer regularly computes his income in keeping his books," 175 despite the section 446(b) "clearly reflect income" limitation. This inference is buttressed by the legislative history of section 446 and its antecedents, which evidence an intent to avoid forcing taxpayers to keep separate books for tax accounting. ${ }^{170}$ The Committee reports to the 1954 Code, commenting on the addition of an authorization for hybrid accounting methods in section $446(\mathrm{c}),{ }^{177}$ consider the example of a "small retail store," which would now be specifically authorized to use its book accounting method for tax returns. ${ }^{178}$ It is possible, then, that an accrual accounting method used by a relatively unsophisticated taxpayer should stand up under 446(b) despite an inaccurate reflection of taxpaying ability. Such an accrual inaccuracy would be tolerated for the sake of accounting simplicity, just as the inaccuracies of the cash method are tolerated for the sake of accounting simplicity.

rent, and providing for interest accruing until the obligation is paid. This characterization would more nearly reflect the economic reality of the deferred rental payment, and would be immune to Commissioner challenge as not "clearly reflecting income" under this analysis, since the discounted value accrual would not defeat horizontal equity.

171. 645 F.2d 523 (5th Cir. 1981).

172. Id. at 527.

173. Id. at 526.

174. See the discussion of cash accounting, supra text accompanying note 163.

175. I.R.C. § 446(a) (1976).

176. See supra note 164 (quoting the 1916 Act Committee Report). Cf. United States v. Anderson, 269 U.S. 422, 440 (1926) (purpose of section 446's predecessor "was to enable taxpayers to keep their books and make their returns according to" the same principles).

177. I.R.C. $\$ 446$ (c) (1976).

178.

One such method, in the case of a small retail store, will be an accrual of items affecting gross income such as purchases, sales of goods, accounts payable, and accounts receivable ... [ [while] items of deduction such as rent, interest, clerks' salaries, insurance and similar items may be accounted for on a cash basis.

House Report, supra note 55, at A158, reprinted in 1954 U.S. Code Cong. \& Ad. News 4017, 4296; Senate Report, supra note 55, at 300, reprinted in 1954 U.S. Code Cong. \& Ad. News 4621, 4939. 
This "exception" to the section 446(b) exception falls apart in the case of taxpayers who structure transactions to exploit accrual accounting inaccuracies. First, such taxpayers hardly fit into the relatively unsophisticated class that accounting simplicity is meant to benefit. ${ }^{179}$ Second, accrual taxpayers structuring tax deferral deals are very likely to be keeping separate tax and financial accounting books already. ${ }^{180}$ Finally, these long term accruals do not fit into the legislative purpose of accrual tax accounting. ${ }^{181}$ If the congressional purpose is consonant with an accountant's understanding of accruals, in authorizing accrual accounting Congress expected most accrued expenses to be paid within one year of the accrual date. ${ }^{182}$ Thus, any legislative purpose to subsidize simplicity of accrual accounting methods will not come into play to protect the taxpayer who intentionally distorts income through long-term expense accruals. ${ }^{183}$

\section{Other Discretionary Factors}

From the above, it can be seen that the primary inquiry under the section 446(b) "clearly reflect income" test is one into tax equity: Is the "income" computed by the taxpayer an adequate index of taxpaying ability, and if it is

179. But cf. Frysinger, 645 F.2d 523 (the taxpayer given the benefit of a farmer's simplified tax accounting method was the treasurer of U.S. Steel). (1981).

180. See generally Weinman, Conformity of Tax and Financial Accounting, 59 Taxes 419

181. Indeed, such long term undiscounted accruals may be at odds with financial accounting. See S. Davidson, C. Stickney, \& R. Weil, Financial Accounting: An Introduction to Concepts, Methods, and Uses 39 ( $2 \mathrm{~d}$ ed. 1979) (long term liabilities "stated at the present value of the future cash outflows"). But compare American Institute of Certified Public Accountants, Committee on Accounting Procedure, Accounting Research Bulletin No. 43, ch. 3, § A-7 (1953), reprinted in Financial Accounting Standards Board, Original Pronouncements as of July 1, 1976, at 13 (1976) (current liabilities include debts "directly related to the [current] operating cycle"), which would seem to place accrued expenses in the category of current liabilities not requiring discounting.

182. S. Davidson, C. Stickney, \& R. Weil, supra note 181, give as examples of "current liabilities ... accounts payable to suppliers, salaries payable to employees, and taxes payable to government agencies," all of which are expense items, and define "current liabilities ... [as] liabilities that are expected to be paid within 1 year." Id. at 6 . On the other hand, the examples given of long-term liabilities are "mortgages, bonds, and [capital] leases." Id. at 364. A capital lease is one in which the asset is effectively purchased. Id. at 386 . While it would be inaccurate to say that financial accounting will not recognize a current expense accrual that will not be paid for over a year, it is fair to say that an expectation arising from experience assumes that current expense accruals will be paid within a year. The dramatic increase in real interest rates since the original tax acts, and even the 1954 Code, have given this assumption an importance that may not have been realized at the time.

183. An example of a situation where the regulations give explicit sanction for current deductions for long-term accruals is original issue discount bonds. Treas. Reg. § 1.163-4(a) (1971) allows the issuer to amortize the bond discount currently even though payment is not made until retirement, which may be decades after issuance. Note, however, that cash method taxpayers must report the amortized discount as current income, even though not received, I.R.C. $\$ \S 1232$, 454 (1976), and that $\S 231$ (a) of the 1982 Tax Equity and Fiscal Responsibility Act, Pub. L. No. 97-248, § 231(a), 96 Stat. 442 (to be codified at I.R.C. § 1232A), adds I.R.C. § 1232A to prohibit 
not, is the difference due to a tax-favored-activity subsidy? It has also been shown that current accruals at full value of payments to be made in the remote future would usually fail the "clearly reflect income" test as thus defined.

This analysis suggests, however, that certain other factors may appropriately be considered by the Commissioner in exercising his discretion in pursuit of the purpose of the tax statute. While tax-avoidance intent is irrelevant to a determination of whether tax equity is defeated, it may be relevant to whether or not the taxpayer's use of an inaccurate book accounting method should be tolerated for simplicity's sake. Further, intent may be the ground for the exercise of a sort of prosecutorial discretion by the Commissioner in performing his duty to "protect the public fisc." Certainly, intentionally abusive tax shelters pose a greater danger to the Treasury than inadvertent accounting inaccuracy, and the proposition that tax avoidance intent is a factor to be considered under section $446(\mathrm{~b})$ has ample case support. ${ }^{184}$

There may also be de minimis situations where, as a matter of administrative convenience, an accrual for expenses to be paid in the future will nevertheless be allowed. The line must be drawn somewhere. Even though every undiscounted accrual distorts income somewhat, ${ }^{185}$ all liabilities to be paid within one or two years should probably be accruable without discount. Setting such a time limit has precedent in the allowance by the Commissioner of prepaid income deferrals of under two years after $A A A$ and Schlude. ${ }^{180}$

\section{CONCLUSION}

The Commissioner has discretion under section 446(b) to disallow accounting methods that do not "clearly reflect income." In exercising this discretion, the "income" that an accounting system must "clearly reflect" is an index of taxpaying ability. "Income" as thus defined comprehends notions of equity and efficiency inherent in a system of income taxation. When the minor inaccuracies of an otherwise acceptable method are emphasized through the purposeful structuring of transactions to gain tax benefits, the corresponding injury to horizontal equity gives the Commissioner a "rational

straight-line amortization of discount and require a compound interest approach that more closely approximates the present value of the future payment.

184. E.g., Thor Power Tool Co. v. Commissioner, 439 U.S. 522, 538 (1979) ("well-known potential for tax avoidance" of inventory accounting invokes disallowance discretion); Ferrill v. Commissioner, 684 F.2d 261, 264 (3d Cir. 1982) (the reason for transaction is a factor to be considered; tax shelter motive supports disallowance); Burck v. Commissioner, 533 F.2d 768, 774 (2d Cir. 1976) ("finding of a tax avoidance motive" supports Commissioner's disallowance). Cf. Frysinger v. Commissioner, 645 F.2d 523, 528 (5th Cir. 1981) (transaction "for a business purpose and not merely tax avoidance"; taxpayer's method upheld). Under such a rule, Grand Ave. Motor Co. and Rev. Rul. 70-119, discussed supra note 28, would still be good law.

185. S. Davidson, P. Stickney, \& R. Weil, supra note 181 , at 360.

186. Rev. Proc. $71-21,1971-2$ C.B. 549,549 ("purpose . . . is to implement an administrative decision, made by the Commissioner in the exercise of his discretion under section 446 of the Internal Revenue Code of 1954'). 
basis" to exercise his discretion to disallow an accounting method. The accrual method of accounting is equally as susceptible to abuse as the cash method, and the "material distortion of income" doctrine for disallowing cash method accounting is properly extended to accrual accounting situations. Disallowance of such accrual abuses gives the Treasury an additional weapon with which to fight transactions designed to defeat the fairness of the income $\operatorname{tax} .{ }^{187}$

Karl S. Coplan

187. Currently, the IRS's principal judicial weapon for fighting tax-avoidance-motivated transactions is the sham transaction doctrine. This doctrine has its origins in the case of Gregory v. Helvering, 293 U.S. 465 (1935). See generally Fuller, Business Purpose, Sham Transactions and the Relation of Private Law to the Law of Taxation, 37 Tul. L. Rev. 355 (1963); Gans, Reexamining the Sham Doctrine: When Should an Overpayment be Reflected in Basis, 30 Buff. L. Rev. 95, 105-09 (1981); Note, Year-End Divorce/Remarriage Schemes and the Applicability of the Sham Doctrine, 3 Cardozo L. Rev. 77, 87-90 (1981).

This doctrine has been expanded in the cases of Knetsch v. United States, 364 U.S. 361 (1960), and Goldstein v. Commissioner, 364 F.2d 734 (2d Cir. 1966). Gregory concerned a corporate reorganization solely for the tax benefits, which the Court declined to recognize for tax purposes. Knetsch and Goldstein held that a transaction entered into without any real hope of economic gain apart from the tax consequences could be disregarded for tax purposes. Both cases involved substantial borrowing and interest prepayments with reinvestment of the loan proceeds in instruments bearing a lower rate of interest than the loan. Thus, the taxpayer could not hope to derive any real gain from the transaction other than the tax deferral from current deductions of interest paid and delay of income recognition until receipt in a later year.

In another variation, the doctrine has been used to deny tax recognition to a sale-leaseback transaction at a grossly inflated price. Estate of Franklin v. Commissioner, 544 F.2d 1045 (9th Cir. 1976). More recently, a similar attack has been made on motion picture tax shelter deals, based on denial of deductions for activities not entered with a profit motive under I.R.C. $\S 183$ (1976). Brannen v. Commissioner, 78 T.C. 471 (1982). But cf. Siegel v. Commissioner, 78 T.C. 659 (1982) (movie tax shelter profit-motivated).

The clear reflection of income analysis would supplement the sham transaction doctrine. The clear reflection of income test can be applied to defeat tax avoidance terms contained within transactions that would meet the tests of nontax economic motivation and reflection of economic reality. 